\title{
Earthquake related tsunami hazard along the western coast of Thailand
}

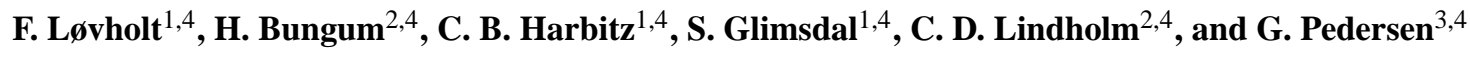 \\ ${ }^{1}$ Norwegian Geotechnical Institute, Oslo, Norway \\ ${ }^{2}$ NORSAR, Kjeller, Norway \\ ${ }^{3}$ University of Oslo, Dept. of Mathematics, Norway \\ ${ }^{4}$ International Centre for Geohazards, Oslo, Norway
}

Received: 26 September 2006 - Revised: 21 November 2006 - Accepted: 21 November 2006 - Published: 30 November 2006

\begin{abstract}
The primary background for the present study was a project to assist the authorities in Thailand with development of plans for how to deal with the future tsunami risk in both short and long term perspectives, in the wake of the devastating 26 December 2004 Sumatra-Andaman earthquake and tsunami. The study is focussed on defining and analyzing a number of possible future earthquake scenarios (magnitudes 8.5, 8.0 and 7.5) with associated return periods, each one accompanied by specific tsunami modelling. Along the most affected part of the western coast of Thailand, the 2004 tsunami wave caused a maximum water level ranging from 5 to $15 \mathrm{~m}$ above mean sea level. These levels and their spatial distributions have been confirmed by detailed numerical simulations. The applied earthquake source is developed based on available seismological and geodetic inversions, and the simulation using the source as initial condition agree well with sea level records and run-up observations. A conclusion from the study is that another megathrust earthquake generating a tsunami affecting the coastline of western Thailand is not likely to occur again for several hundred years. This is in part based on the assumption that the Southern Andaman Microplate Boundary near the Simeulue Islands constitutes a geologic barrier that will prohibit significant rupture across it, and in part on the decreasing subduction rates north of the Banda Ache region. It is also concluded that the largest credible earthquake to be prepared for along the part of the Sunda-Andaman arc that could affect Thailand, is within the next $50-100$ years an earthquake of magnitude 8.5 , which is expected to occur with more spatial and temporal irregularity than the megathrust events. Numerical simulations have shown such earthquakes to cause tsunamis with maximum water levels up to $1.5-2.0 \mathrm{~m}$ along the western coast of Thailand, possibly $2.5-3.0 \mathrm{~m}$ on a high tide. However, in a longer time perspective (say more than 50-100 years) the potentials
\end{abstract}

Correspondence to: F. L $\emptyset$ vholt

(flo@ngi.no) for earthquakes of similar magnitude and consequences as the 2004 event will become gradually larger and eventually posing an unacceptable societal risk. These conclusions apply only to Thailand, since the effects of an M 8.5 earthquake in the same region could be worse for north-western Sumatra, the Andaman and Nicobar Islands, maybe even for Sri Lanka and parts of the Indian coastline. Moreover, further south along the Sunda arc the potentials for large ruptures are now much higher than for the region that ruptured on 26 December 2004.

\section{Introduction}

The 26 December 2004 Indian Ocean tsunami is the most destructive tsunami in modern times; it caused in the range of 2-300 000 casualties. The tsunami was generated by the gigantic magnitude 9.1-9.3 Sumatra-Andaman earthquake (Stein and Okal, 2005; Kanamori, 2006) caused by propagating stress release on the subduction zone created by the steadily ongoing northeast subduction of the Indo-Australian plate under the Burma/Sunda plate, along the Sunda arc. The earthquake caused vertical seabed movements of up to 4-5 m (Banerjee et al., 2005; Subarya et al., 2006) over a total area of about $1200 \mathrm{~km}$ by $300 \mathrm{~km}$. A large number of papers have already been published on this earthquake and on its tectonic setting (e.g., Lay et al., 2005; Ammon et al., 2005).

The largest destruction caused by the 2004 Indian Ocean tsunami is found in the Ache region closest to the earthquake epicentre, with maximum tsunami run-up values of more than $30 \mathrm{~m}$, and with run-up of 10-20 m along large sections of the coastline (Japanese survey team, 2006a; Yalciner et al., 2005; Borrero et al., 2006; Jaffe et al., 2006). Moreover, devastating effects are found over an enormous geographical area, with dominating run-up and maximum water level of 5-10 $\mathrm{m}$ along the shorelines of Andaman, Nicobar, Sri Lanka, and western Thailand, and several meters along

Published by Copernicus GmbH on behalf of the European Geosciences Union. 
most of the eastern Indian coastline, Myanmar, Malaysia, the Maldives, and parts of eastern Africa (Synolakis and Kong, 2006; Japanese survey team, 2006a; Yalciner et al., 2005; Papadopoulos et al., 2006). An extensive collection of field surveys reporting the run-up, maximum water levels, and damage for most affected countries in the Indian Ocean is given in a special issue of Earthquake Spectra (see Iwan, 2006).

The 2004 Indian Ocean tsunami raised a number of questions on how to deal with tsunami hazard and risk, including early warning. Evaluating the risk for all the countries potentially affected by tsunamis generated by earthquakes along the Sunda arc is a formidable task. Hence as a small contribution to this end, we limit our study on potential tsunami hazard to western Thailand, using a scenario based approach. The present paper is based on a project to assist the authorities in Thailand with evaluating the future tsunami risk and to develop plans for how to deal with the risk, with main purpose to establish practical guidelines for land use and rehabilitation of the exposed areas. The results of this project are presented by NGI (2006), and also briefly presented by Karlsrud et al. (2005).

Benefit is also made from the experience gained by Glimsdal et al. (2006), which studied sensitivity to earthquake sources and dispersion. However as opposed to Glimsdal et al. (2006) this paper also includes a hazard study of potential earthquake generated tsunamis. In addition, the present simulation of the 2004 Indian Ocean tsunami is based on updated information about the earthquake, and we compare our results with a larger amount of measured sea level and run-up data.

The first part of this paper describes the rupture process and how this is represented in our modelling of the 26 December 2004 Sumatra-Andaman tsunami. Next, our numerical modelling of the 2004 Indian Ocean tsunami is documented in more detail, including comparison with observations and energy calculations. Then the locations and magnitudes of scenarios for possible future earthquakes, and their respective return periods are presented. The earthquake scenarios are then used as input to numerical tsunami simulations, and tsunami design criteria for Thailand based on these simulations are presented. Based on NGI (2006), this paper concludes with a brief discussion of tsunami risk, including some proposed mitigation measures along the coast of Thailand.

\section{The 26 December 2004 Sumatra-Andaman earth- quake}

\subsection{The rupture process}

The 26 December 2004 Sumatra-Andaman earthquake is still known only to a first order, in particular with respect to the distribution of stress, asperities and dislocations in the focal region. These factors largely govern the patterns of surface rupture along the fault as well as the spatial (and temporal) distribution of seabed dislocations, which in turn controls the generation of the tsunami. Even so, there are already a large number of papers which are addressing this (e.g., Ammon et al., 2005; Banerjee et al., 2005; Bilham et al., 2005; Ishii et al., 2005; Park et al., 2005; Lay et al., 2005; Stein and Okal, 2005; Subarya et al., 2006; Titov et al., 2005; Vigny et al., 2005), and many more will appear in the near future.

The earthquake rupture initiated west of the northern tip of Sumatra, near the Simeulue Island. Within ten minutes after initiation, the earthquake slip had propagated about $1200 \mathrm{~km}$ northwards from the epicentre, but in a very complicated way and with significant variations along the way in terms of rupture velocity, slip, and energy release, as shown by $\mathrm{Ni}$ et al. (2005) and Krüger and Ohrnberger (2005). The rupture velocity was highest in the south, slowing down further north according to Bilham (2005). However, Wang and Liu (2006) suggested that the rupture speed may have sustained northwards.

\subsection{Earthquake source model}

For the simulation of the 2004 Indian Ocean tsunami, the earthquake source is established through an iterative process to ensure that it largely complies with the available seismic and geodetic information described above, and at the same time produces tsunami heights and arrival times in agreement with observations. The earthquake source is a simplified version of, but still largely consistent with, published results, and it is composed of individual segments described in Table 1. For each segment the position, dip angle, dipslip, strike-slip, width, and sea depth over the fault are specified. It has been assumed here that the average rigidity on the rupture plane for the megathrust event is $40 \mathrm{GPa}$ (Bilek and Lay, 1999), which for the segments combined gives a released seismic moment corresponding to a magnitude $\left(\mathrm{M}_{W}\right)$ of 9.28. The constant shear modulus is yet another simplification for a parameter which in the real case should be expected to vary considerably both horizontally and vertically.

A method based on an analytical model (Okada, 1992) is used to convert composite earthquake slip motions to seabed displacements, and the response of a number of segments that are treated as independent faults is computed. Okada's model has been applied differently in literature with respect to extending the fault to the seabed surface. Initially, the tip of the fault segment was located a few kilometres below the seabed, which however resulted in artificial displacements that dominated locally above the tip of the fault in the proximity of the trench. The artificial displacements had typical wavelengths of the same order as the distance from the fault tip to the seabed, hence orders of magnitude smaller than the dominating seabed displacement length. Moreover, the initial maximum surface elevation was doubled. Because of the artificial effect, the model is not considered reliable when the fault is buried; consequently the average slip motion values 


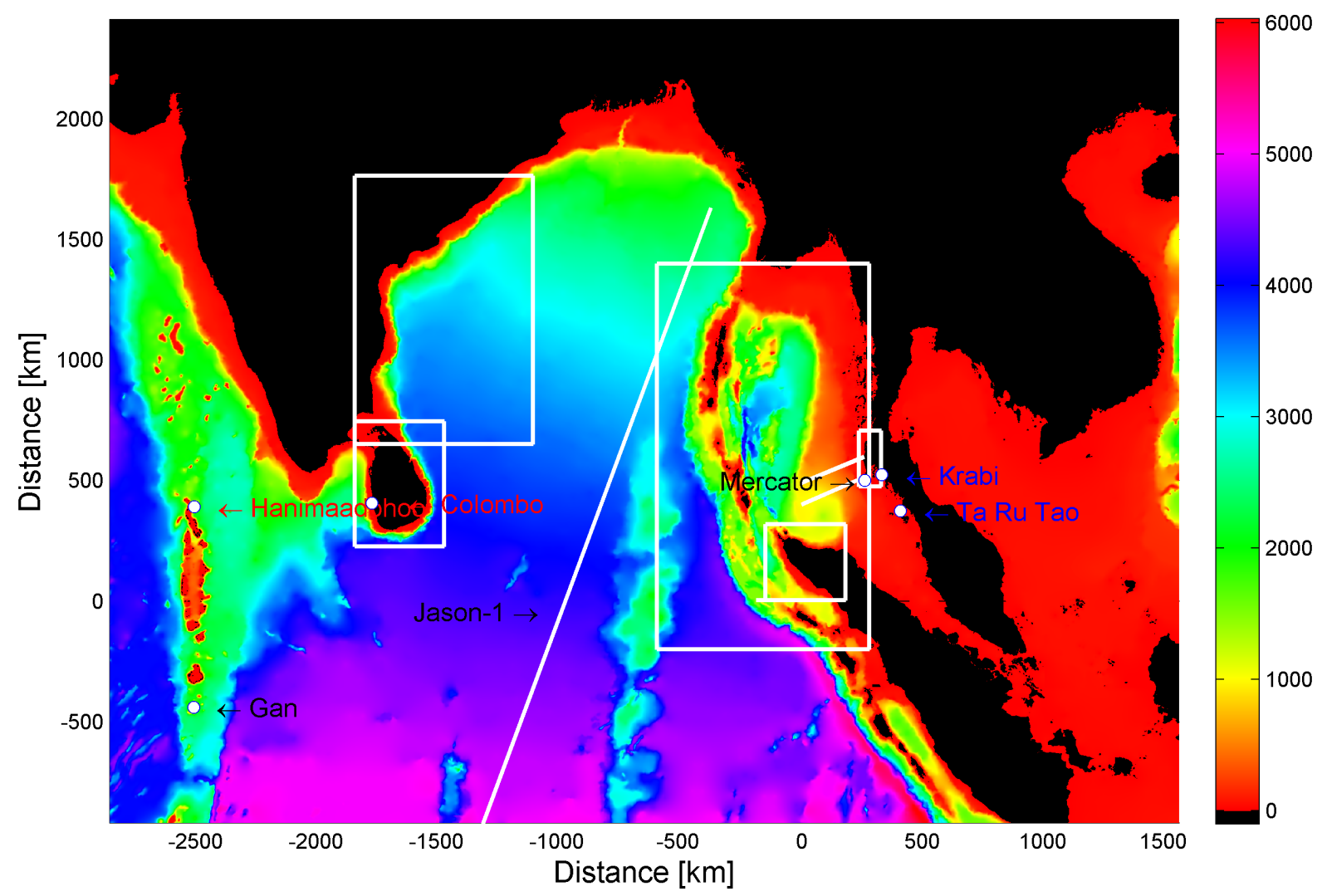

Fig. 1. Water depths in the Indian Ocean. The white boxes indicate the extent of the maps in Fig. 2, and in Figs. 6 through 8 . The white lines indicate the cross sections used in the one-dimensional numerical model, and the trajectory of the satellite Jason- 1 . The locations of the sea level gauges given in Fig. 4 are shown as white circles. The colourbar indicating the water depth in meters, are also used subsequently in Figs. 6 through 8 .

are transferred unchanged to the surface instead. A linear variation is assumed along the fault segment. The computation of the seabed displacement is not implying any energy loss mechanisms, which is a conservative assumption.

The initial sea surface displacement is copied from the bottom deformation, except near discontinuities at the fault line where a two-dimensional solution of the Laplace equation established by application of matched asymptotics is employed in cross-sections as a kind of "stripe" theory to give a smooth surface with finite gradients (Pedersen, 2001).

The proposed source is in general agreement with different reconstructions of the earthquake slip distribution using geodetic data (e.g. Subarya et al., 2006; Chlieh et al., 2006); however, the uniform slip in the dip direction is an important simplification compared to the geodetic reconstructions. Nevertheless, this assumption was maintained, partly because the method should be used for modelling smaller earthquake scenarios as well, and partly because the detailed slip distribution is still not known. Finally, the northward delay of rupture along the fault is not included. This might marginally affect the arrival times and the spatial distribution of run-up heights, see Glimsdal et al. (2006) and Wang and Liu (2006) for discussions.

\section{Simulation of the 2004 Indian Ocean tsunami}

\subsection{Applied model and grid}

A linear shallow water (LSW) numerical model is used for the two-dimensional (depth-averaged with two horizontal dimensions) simulation of the 2004 Indian Ocean tsunami. In the LSW model, the shore line is represented by a vertical and impermeable wall (no-flux boundary conditions), providing a doubling of the surface elevation due to reflection. It is found that the longest waves encountered are shorter than the Rossby radius (see e.g. Gill, 1982), and neglecting the rotational Coriolis effect is therefore considered acceptable. The LSW model is solved numerically on a staggered grid in time and space, often referred to as the Arakawa C-grid (Mesinger and Arakawa, 1976). Model stability is ensured by adjusting the time step through the CFL criterion. It should moreover be noted that effects of dispersion is not included in the LSW model. The study by Glimsdal et al. (2006) concludes that effects of dispersion are not important for the open ocean propagation. For further details on the numerical LSW model, see Harbitz and Pedersen (1992). 
Table 1. Scenario earthquake segmentation and parameterization for use in tsunami modeling. The columns denote rigidity, segment length, width and slip in both ends of each segment (from $\mathrm{S}$ to $\mathrm{N}$ ), seismic moment and corresponding magnitude. The last line gives the total numbers for each event.

\begin{tabular}{lllllllll}
\hline & $\begin{array}{l}\text { Rigidity } \\
(\mathrm{GPa})\end{array}$ & $\begin{array}{l}\mathrm{L} \\
(\mathrm{km})\end{array}$ & $\begin{array}{l}\text { W1-S } \\
(\mathrm{km})\end{array}$ & $\begin{array}{l}\text { W2-N } \\
(\mathrm{km})\end{array}$ & $\begin{array}{l}\mathrm{S} 1-\mathrm{S} \\
(\mathrm{m})\end{array}$ & $\begin{array}{l}\mathrm{S} 2-\mathrm{N} \\
(\mathrm{m})\end{array}$ & $\begin{array}{l}\text { Moment } \\
(\mathrm{Nm})\end{array}$ & $\begin{array}{l}\text { Mag. } \\
\mathrm{M}_{W}\end{array}$ \\
\hline & 40 & 182.5 & 210 & 160 & 17.5 & 18 & $2.07 \mathrm{E}+22$ & 8.82 \\
& 40 & 181.2 & 210 & 160 & 17 & 17.5 & $2.00 \mathrm{E}+22$ & 8.81 \\
& 40 & 94 & 160 & 140 & 5 & 5 & $2.82 \mathrm{E}+21$ & 8.24 \\
& 40 & 185 & 140 & 155 & 19 & 15 & $1.84 \mathrm{E}+22$ & 8.78 \\
& 40 & 185 & 155 & 170 & 12 & 19 & $1.88 \mathrm{E}+22$ & 8.79 \\
& 40 & 185 & 170 & 210 & 9.2 & 11.1 & $1.44 \mathrm{E}+22$ & 8.71 \\
M 9.28 & 40 & 189 & 210 & 210 & 6 & 4 & $7.94 \mathrm{E}+21$ & 8.54 \\
& 30 & 1200 & & & & & $1.09 \mathrm{E}+23$ & 9.28 \\
& 30 & 160 & 100 & 100 & 7.25 & 0 & $1.74 \mathrm{E}+21$ & 8.10 \\
& 30 & 160 & 100 & 100 & 7.25 & 7.25 & $3.48 \mathrm{E}+21$ & 8.30 \\
M 8.5 & & 480 & & 100 & 0 & 7.25 & $1.74 \mathrm{E}+21$ & 8.10 \\
& 20 & 50 & 30 & 30 & 3.625 & 0 & $6.96 \mathrm{E}+21$ & 8.50 \\
& 20 & 50 & 30 & 30 & 3.625 & 3.625 & $1.09 \mathrm{E}+20$ & 7.30 \\
& 20 & 50 & 30 & 30 & 0 & 3.625 & $5.44 \mathrm{E}+19$ & 7.10 \\
M 7.5 & & 150 & & & & & $2.17 \mathrm{E}+20$ & 7.50 \\
& 15 & 28 & 17.5 & 17.5 & 2.625 & 0 & $9.65 \mathrm{E}+18$ & 6.60 \\
& 15 & 28 & 17.5 & 17.5 & 2.625 & 2.625 & $1.93 \mathrm{E}+19$ & 6.80 \\
& 15 & 28 & 17.5 & 17.5 & 0 & 2.625 & $9.65 \mathrm{E}+18$ & 6.60 \\
M 7.0 & & 84 & & & & & $3.86 \mathrm{E}+19$ & 7.00 \\
\hline
\end{tabular}

The bathymetric grid used for the two-dimensional simulations is shown in Fig. 1; based on the General Bathymetric Chart of the Ocean (GEBCO), with 1 min resolution $(1.84 \mathrm{~km} \times 1.85 \mathrm{~km})$. Transformation into a Cartesian grid coordinate system is performed using a cylindrical projection. This linearization gives no error for north-south and insignificant errors for east-west directions within our computational domain. The error at $15^{\circ} \mathrm{N}$ (i.e. $1300 \mathrm{~km}$ north of epicentre) is less than $3 \%$ within the Bay of Bengal, decreasing to zero at the latitude of the epicentre.

Using the two-dimensional LSW model described above, we performed a simulation of the 2004 Indian Ocean tsunami using the initial condition shown in Fig. 2. Snapshots of the calculated surface elevations in the Bay of Bengal after 40 and $80 \mathrm{~min}$ are shown in Fig. 3.

To investigate convergence, we compare simulated time series on the $1^{\prime}$ grid with simulated time series on coarser grids with resolutions of $2^{\prime}$ and $4^{\prime}$. For example, at Bang Niang, Thailand, with depth $33 \mathrm{~m}$, we find for the first wave pulse a discrepancy of $25 \%$ between the $2^{\prime}$ and $4^{\prime}$ grids, and $8 \%$ between the $1^{\prime}$ and the $2^{\prime}$ grids. For the location of Mercator (see Fig. 1) at a depth of $13 \mathrm{~m}$, the discrepancy between the $1^{\prime}$ and the $2^{\prime}$ grids for the first wave pulse is $12 \%$. Other time series locations gave similar results. Because the convergence rate for the numerical model is quadratic, we can roughly expect errors less than $3 \%$ between $0.5^{\prime}$ and $1^{\prime}$ grids for depths larger than $10 \mathrm{~m}$. For the regional study performed here, we therefore find the grid resolution and accuracy of the map projection to be sufficient, as also supported by earlier investigations (Glimsdal et al., 2006).

\subsection{Comparison with sea level measurements}

The two-dimensional simulation is compared to corresponding tide-gauge records at $\mathrm{Ta} \mathrm{Ru}$ Tao and Krabi (southern Thailand), Gan and Hanimaadohoo (Maldives), and Colombo (Sri Lanka), (see e.g. Merrifield et al., 2005; Japanese survey team, 2006b), and sea-level recordings from the yacht Mercator located about $2 \mathrm{~km}$ outside Nai Harn Bay, Phuket Island (KNMI web page, 2005), as shown in Fig. 4. Geographical co-ordinates were not found for several of the sea level records and when they were found, they often corresponded to erroneous locations in the computational grid due to coarse grid resolution and small projection errors. Therefore, the locations of the sea level records are corrected manually. In addition, sparse sampling rates limit detailed comparisons for some of the sea level records. The sea level records are mostly located near the coast (Merrifield et al., 2005), and one should preferably make use of local bathymetries for capturing local effects. However, studying local effects is beyond the scope of this paper.

The time series in Fig. 4 show several wave cycles, with dominating wave periods in the range of 20 to $40 \mathrm{~min}$. Indeed, keeping in mind various sources of errors (elaborated 
below), and the geographical spread of the observations, the computed wave characteristics (i.e. amplitudes and periods) agree reasonably well with the sea level observations as a whole. However, a more detailed investigation of the time series in Fig. 4 reveals discrepancies that need further attention. From Fig. 4, we see that:

1. Two computed time series located approximately $10 \mathrm{~km}$ from each other, are compared with one sea level observation at $\mathrm{Ta} \mathrm{Ru}$ Tao. Only one of them (solid line) gives good correspondence with the sea level data, the other one (dashed line) gives a longer wave period and a larger maximum surface elevation. The difference between the two computed time series shows that local effects can cause large differences in the wave evolution within short distances.

2. The dominating wave period is overestimated for the location of Mercator. The discrepancy may be due to a combination of local effects not captured in the tsunami model, and short wave components that are not included in the synthetic earthquake source model.

3. Computed arrival times deviate from observed ones in most locations. Because all the time series are located in shallow water, the arrival time is sensitive to the location of the time series, as well as to grid effects. In particular, the deviation of $30 \mathrm{~min}$ at the Krabi location appears as strange, as the wave shape is mimicked well in the computations. A possible reason for the deviation may be errors in the applied bathymetry, but most likely this is due to errors in reference time as reported by Tsuji and Satake (2006).

4. Pronounced short-period wave components are found in the computed time series at Hanimaadohoo and Gan. The periods are approximately $5 \mathrm{~min}$, resulting in wavelengths of approximately $5 \mathrm{~km}$ that are only covered by 3 grid cells in each horizontal direction, and are therefore not properly resolved. The short-period components may be caused by grid effects, or more precisely stair case boundaries (Pedersen, 1995).

5. The withdrawal amplitude is slightly overestimated in most of the computed time series. The overestimation might be a result of lack of damping in the earthquake dislocation model and the Okada parameterization, giving too large amplitudes for the negative surface displacements.

By chance, the Jason-1 satellite (see e.g. Smith et al., 2005) recorded the tsunami as it passed over the Indian Ocean. The recording started approximately $1 \mathrm{~h} 55 \mathrm{~min}$ after the tsunami was generated, and used about $8 \mathrm{~min}$ to traverse the path from south to north. A comparison with the data from the Jason1 satellite is shown in Fig. 5 for three different simulation

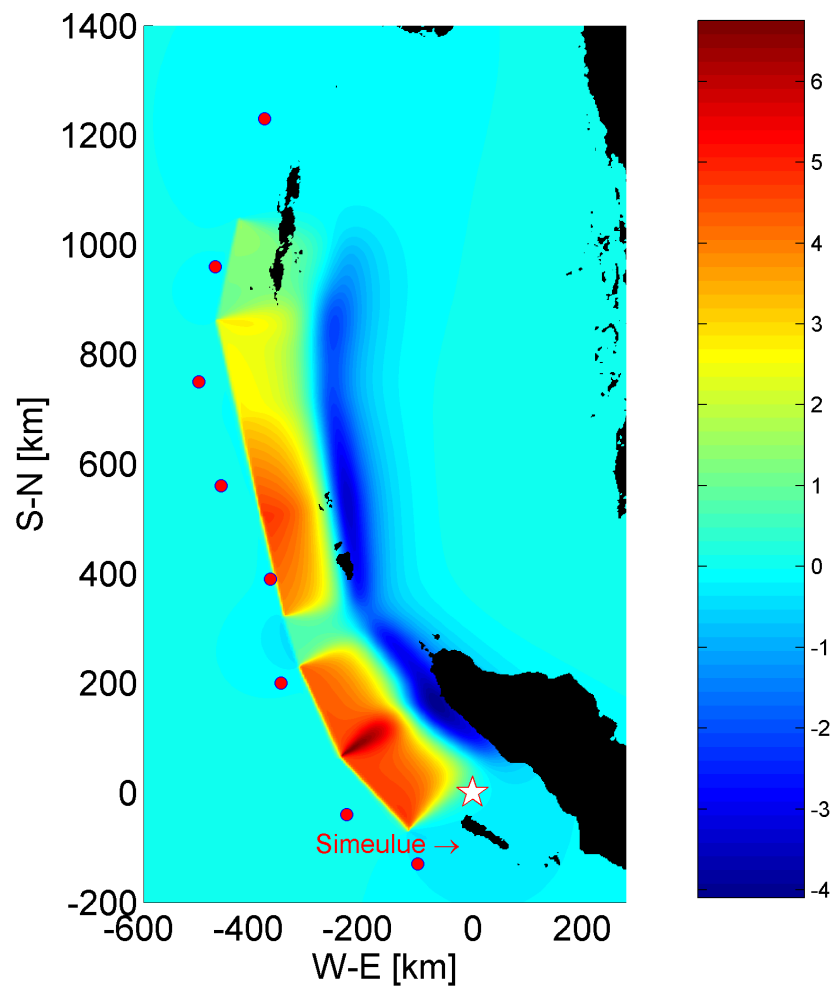

Fig. 2. The initial sea surface elevation used for the simulation of the 2004 Indian Ocean tsunami. The white star indicates the epicentre. The boundary between the Indian Plate and the Burma plate is indicated with red bullets.

times. Along the southernmost part of the profile, the simulation taken at $1 \mathrm{~h} 55 \mathrm{~min}$ compare rather well with Jason-1. Northward, the results are not matching as well, which can be explained from several reasons. First, the calculated surface elevation is evaluated exactly at one given time along the trajectory. Next, parts of the wave crests (approximately between latitudes $5-15^{\circ}$ north) are almost parallel to the trajectory of Jason-1, which means that a slight spatial or temporal shift gives a large effect on the surface elevation. Sensitivity is also illustrated by evaluating the surface elevation $3 \mathrm{~min}$ before and $3 \mathrm{~min}$ after the start of the recording, giving errors in the surface elevation up to $100 \%$ even along the southernmost part of the profile, caused by a shift in phase of approximately $30^{\prime}$ (i.e. about $50 \mathrm{~km}$ ). Moreover, the increased discrepancy northward could be explained by a non-uniform slip distribution in the dip direction, as suggested by Wang and Liu (2006). In addition, the waves observed along the northernmost part of the Jason-1 path are strongly influenced by reflections from islands, as shown already after $80 \mathrm{~min}$ of propagation (Fig. 3), making the wave field hard to mimic. 

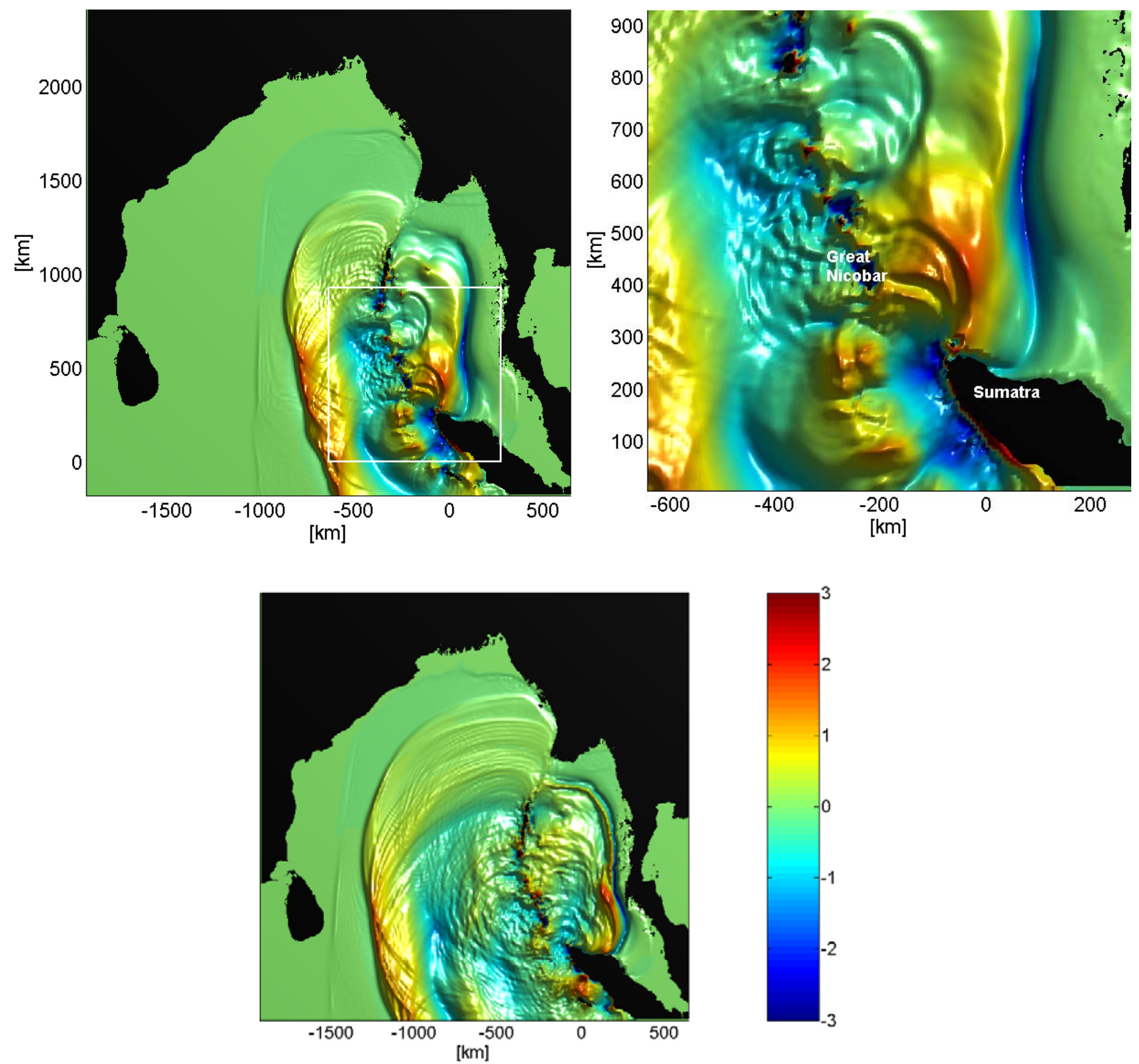

Fig. 3. Simulation snapshots of the 2004 Indian Ocean tsunami in the Bengal Bay and the Andaman Sea. Upper left panel: surface elevation after $40 \mathrm{~min}$; Upper right panel: close-up of the inner frame of the upper left figure; Lower panel: surface elevation after 80 min.

\subsection{Comparison with run-up heights and maximum water levels}

The two-dimensional simulations have been compared with observations of run-up heights and maximum water levels (according to the definitions of the Intergovernmental Oceanographic Commission of UNESCO, 2006) along the coastlines of western Thailand, eastern India (Fig. 6), northern Sumatra (Fig. 7) and Sri Lanka (Fig. 8). Run-up data are taken from the Japanese survey team (2006a), University of Poznan (2005), Yalciner et al. (2005) for Thailand and Sumatra, and from Geological Survey of India (2005) and Yeh et al. (2006) for south-eastern India. Maximum water levels for Sri Lanka are taken from Liu et al. (2005). The figures do not cover all data points in the various investigations, but represent typical data used for comparison with the simulations mentioned above, as the run-up may vary on local scales that are below the grid resolution in the model. Their 

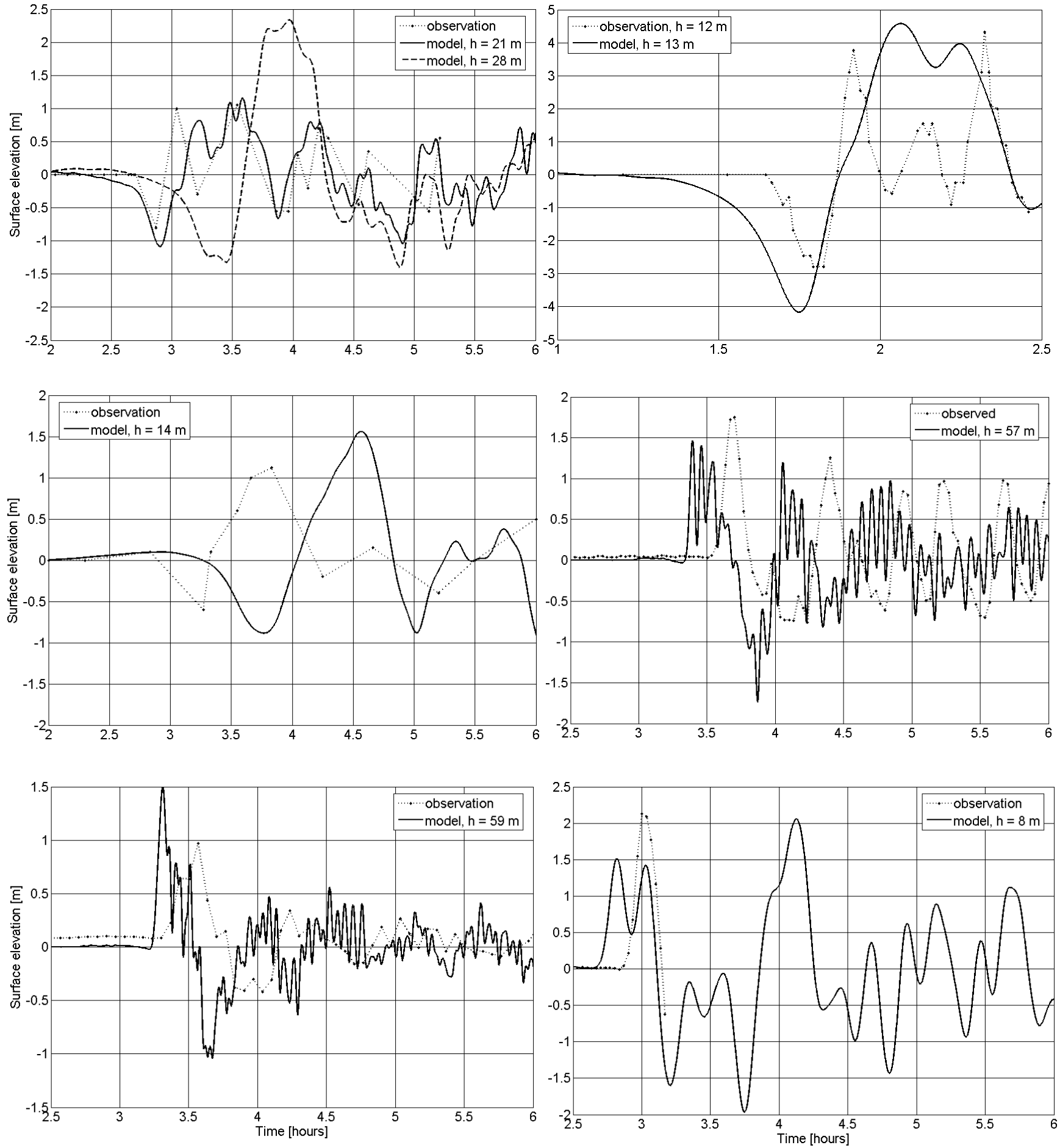

Fig. 4. Comparison of computed surface elevation time series of the 2004 Indian Ocean tsunami with observations at Ta Ru Tao (upper left panel), Mercator (upper right panel), Krabi (mid left panel), Hanimaadohoo (mid right panel), Gan (lower left panel), and at Colombo (lower right panel). The times series at Ta Ru Tao and Krabi are taken from Japanese survey team (2006b); Hanimadohoo, Gan, and Colombo from Merrifield et al. (2005); and Mercator from KNMI web page (2005). 
Table 2. Total wave energies of ancient and historical tsunamis.

\begin{tabular}{llll}
\hline Tsunami & Source & $\begin{array}{l}\text { Estimated tsunami } \\
\text { energy }[\mathrm{J}]\end{array}$ & Background data \\
\hline 2004 Indian Ocean & Earthquake & $3.5 \times 10^{15}$ & This paper \\
1998 Papua New Guinea & Landslide & $8 \times 10^{13}$ & Okal and Synolakis (2003) \\
1964 Alaska & Earthquake & $2 \times 10^{15}$ & Kajiura (1981) \\
1960 Chile & Earthquake & $1 \times 10^{16}$ & Kajiura (1981) \\
1886 Krakatau & Volcano & $1 \times 10^{16}$ & Choi et al. (2003) \\
8100 BP Storegga & Landslide & $4 \times 10^{16}$ & Bondevik et al. (2005) \\
142 MY BP Mjølnir & Asteroid impact & $2 \times 10^{18}$ & Glimsdal et al. (2006) \\
\hline
\end{tabular}

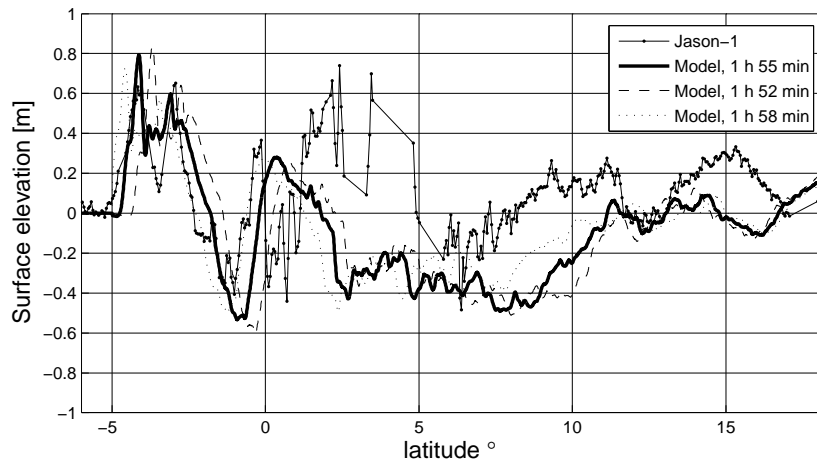

Fig. 5. Comparison of the simulation of the 2004 Indian Ocean tsunami with the recordings of Jason-1 (Smith et al., 2005) for three different times of simulation.

positions along the coastline are plotted manually together with the simulated maximum surface elevations $\left(\eta_{\max }\right)$ in Fig. 6 through Fig. 8.

For the coastlines investigated here, the wave lengths are in general long compared to the run-up zone. Hence, the amplification is limited and fairly well described by no-flux boundary conditions along the shoreline. This is supported by runup profiles in Thailand and Sumatra, indicating that the inundation levels did not increase inland from the shore (NGI, 2006, page B5; Jaffe et al., 2006). For the regional study performed here, it was decided to compare the maximum surface elevations close to the shoreline instead of performing explicit run-up simulations, partly because a large number of run-up simulations are hardly feasible, and partly because a run-up model capturing the effects of the muddy flow observed on videos (http://www.asiantsunamividoes.com) far onshore is not available.

The maximum surface elevations considered in this study are restricted to ocean depths larger than $10 \mathrm{~m}$. The sensitivity to the limit depth was tested for depths of 5 and $20 \mathrm{~m}$, as illustrated for Thailand in Fig. 6. A distinct increase in $\eta_{\text {max }}$ from 20 to $10 \mathrm{~m}$ depth is shown; however $\eta_{\max }$ does not increase similarly for depths from 10 to $5 \mathrm{~m}$. The same con- clusion has also been reached for other locations. In addition, the amplification due to shoaling at different depths compares favourably with Green's law (see e.g. Mei, 1989). The typical surface elevation-to-depth ratios defined as $\alpha=\eta_{\max } / \mathrm{h}$ are then in the range of $0.1-1$ for depths larger than $10 \mathrm{~m}$, except for the coastline of northern Sumatra where the largest $\alpha$ values are close to 2 . Although values of $\alpha>0.1$ represent data above the validity of the linear model, using the results beyond the linear limit has been proven useful in a similar investigation by Løvholt et al. (2005). The limit value of $10 \mathrm{~m}$ is therefore a reasonable compromise to ensure that the shoaling effect is taken into account, that the artificial grid effects are kept reasonably low, and that the violation of the linear limit is restricted.

Figures 6 through 8 show that the spatial distributions of the calculated maximum surface elevations correspond remarkably well with the observed run-up distribution, and in several locations also with the run-up height. However, our regional study fail to capture all details of the run-up distribution, as should be expected since the model lacks a fine grid, local bathymetries, and run-up calculations. For example, the extreme run-up of $+30 \mathrm{~m}$ at Lhoknga (Borrero et al., 2006) at northern Sumatra is not captured. Next, the simulation gives smaller elevations along south western Sri Lanka than reported in the field investigation of Liu et al. (2005), who reports that the largest destructions in western Sri Lanka were caused by the third positive wave. This is obviously not properly captured in our simulation. Finally, $\eta_{\max }$ close to Banda Ache is generally about one half of the observed runup heights. One likely reason for the small values of $\eta_{\max }$, is that wave propagation through the strait between Sumatra and the islands to the north is prohibited in the applied grid.

Figure 6 shows that the run-up distribution along Thailand is reasonably well represented by $\eta_{\max }$ in the simulation, although $\eta_{\max }$ is slightly larger than the observed run-up north of Bang-Niang, and along parts of central Phuket. However, previous investigations with several other earthquake models gave results with a markedly more even distribution of $\eta_{\max }$, failing to reproduce the observed northward increase in run-up along Thailand. In Fig. 3, one can see a diffracted 

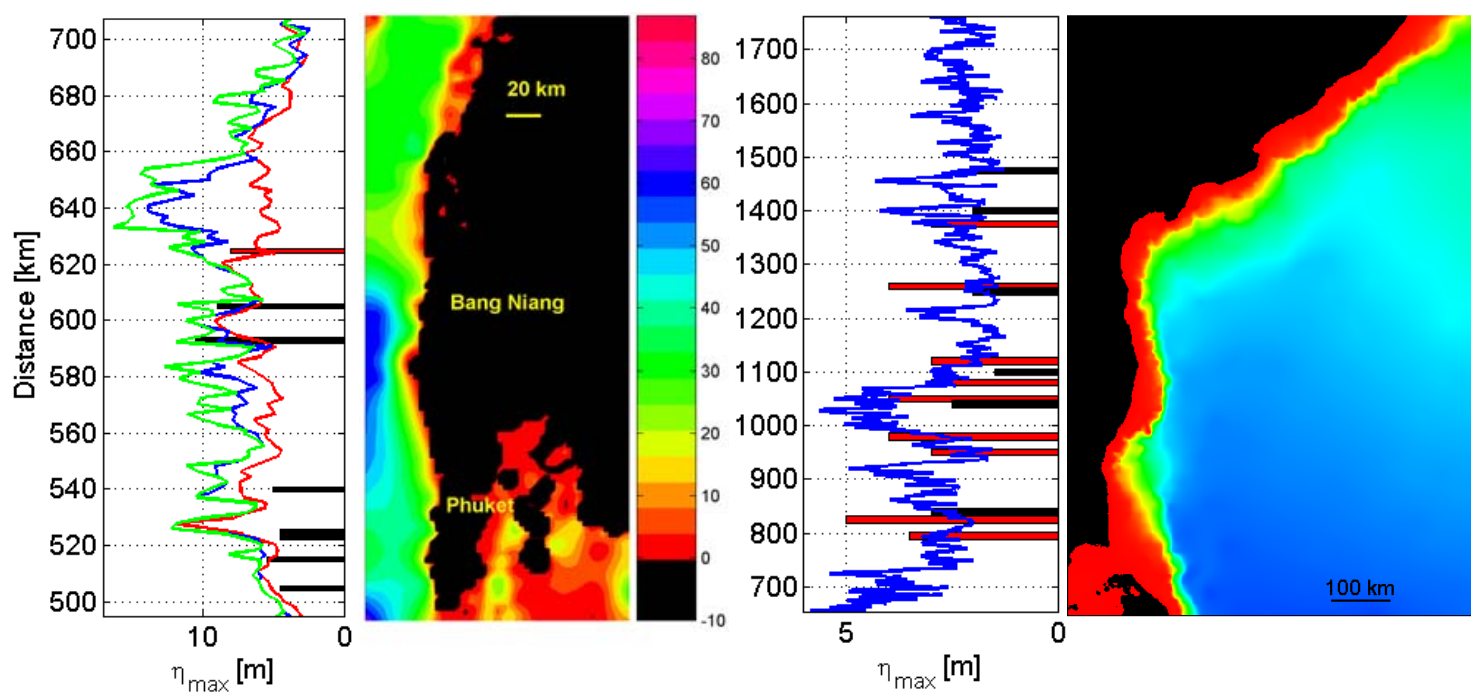

Fig. 6. Simulation of the 2004 Indian Ocean tsunami. Left panel: Maximum computed surface elevation in western Thailand using the LSW model for depths larger than $5 \mathrm{~m}$ (green line), $10 \mathrm{~m}$ (blue line), and $20 \mathrm{~m}$ (red line), compared with observed run-up heights (black bars Japanese survey team, 2006a; red bar University of Poznan, 2005). The mid left panel shows the water depth in western Thailand, where the colourbar gives water depths in $\mathrm{m}$. The mid right panel shows the maximum computed surface elevation in south-eastern India using the LSW model for depths larger than $10 \mathrm{~m}$ (blue line), compared with observed run-up (black bars, Geological Survey of India, 2005; red bars Yeh et al., 2006). The right panel shows the water depth in south-eastern India (colourbar given in Fig. 1).
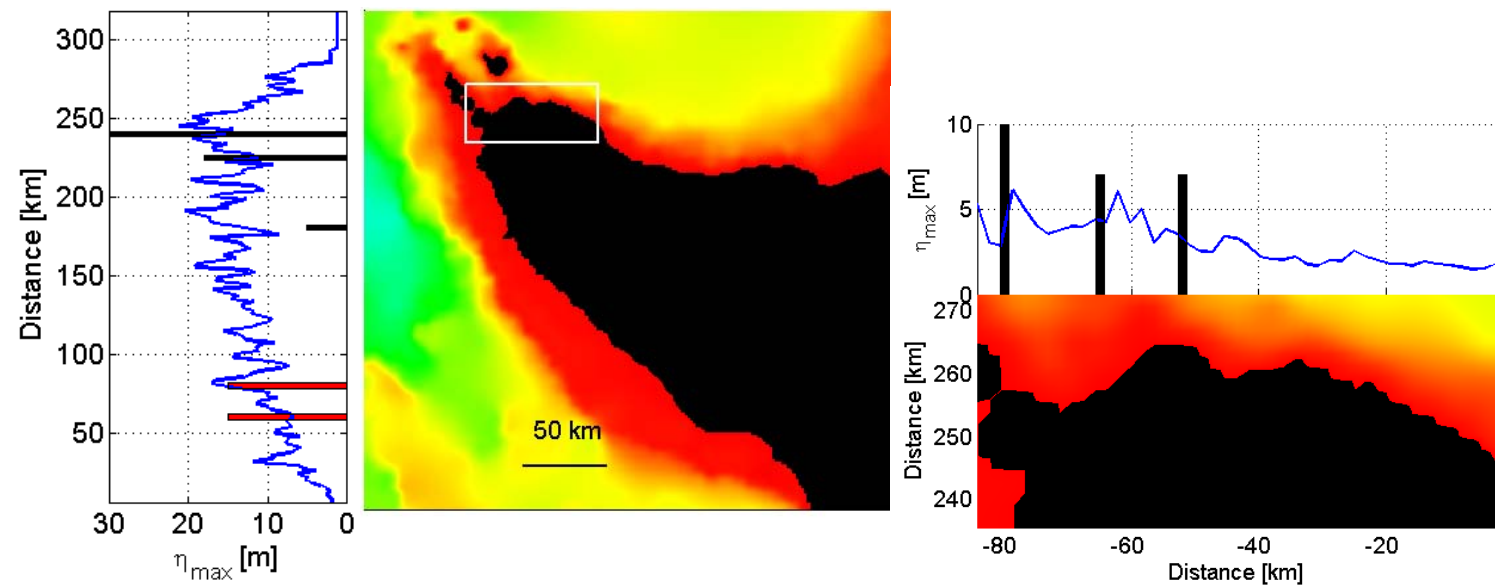

Fig. 7. Left panel: Maximum computed surface elevation in northern Sumatra using the LSW model for depths larger than $10 \mathrm{~m}$ (blue line), compared with observed run-up (black bars, Japanese survey team, 2006a; red bars Yalciner et al., 2005). Mid panel: Water depth at northern Sumatra (colourbar given in Fig. 1), where the white box indicates the extent of the lower right map of Banda Ache. Upper right panel: Maximum computed surface elevation in Banda Ache using the LSW model for depths larger than $10 \mathrm{~m}$ (blue line), compared with observed run-up (bars) of Japanese survey team (2006a). Lower right panel: Water depth in northern Banda Ache (colourbar given in Fig. 1).

wave emerging between northern Sumatra and Great Nicobar, being responsible for the main damage along Thailand. Moreover, this wave is interfering with a wave emerging between the Nicobar and Andaman Islands, which finally give the complicated distribution of $\eta_{\max }$ along western Thailand as shown in Fig. 6. Northwards from Phuket, the slope in- clination of the continental margin decreases, which could in addition explain some of the increase in run-up.

\subsection{Energy of the 2004 Indian Ocean tsunami}

The potential energy $E_{0}$ of the initial surface elevation of a water wave at rest can be found by integrating the initial 

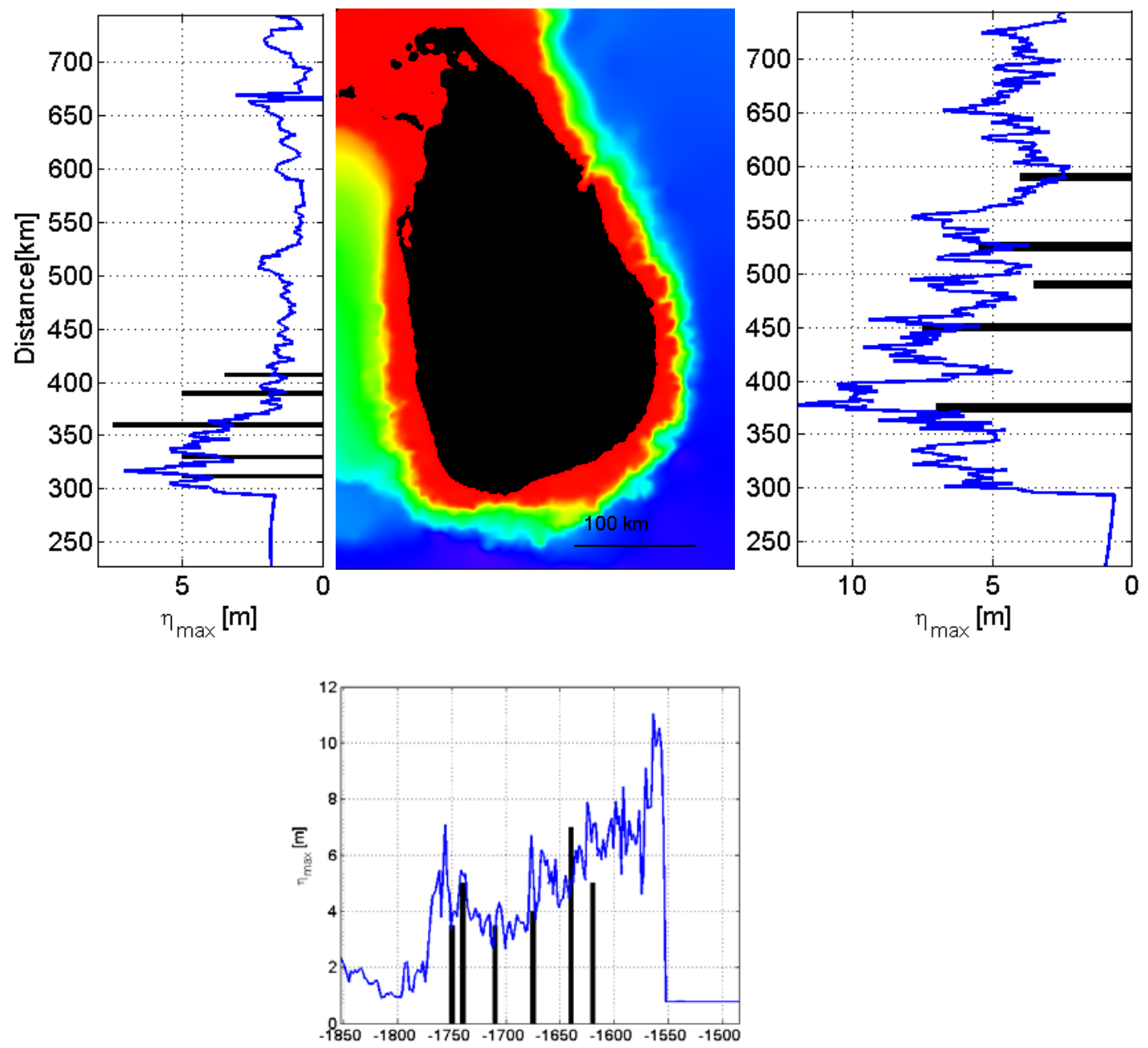

Fig. 8. Maximum computed surface elevation using the LSW model for depths larger than $10 \mathrm{~m}$ (blue line) compared with observed maximum water levels (bars) of Liu et al. (2005) at the western (upper left panel), eastern (upper right panel) and southern (lower panel) coastlines of Sri Lanka. The upper central panel shows the water depth aournd Sri Lanka (colour bar is given in Fig. 1).

squared surface elevation over the whole computational domain $\Omega$ according to the expression

$E_{0}=\frac{1}{2} \rho g \iint_{\Omega} \eta^{2} d \Omega$.

Integrating the initial condition given in Fig. 2, we find for the 2004 Indian Ocean tsunami $E_{0} \approx 3.5 \times 10^{15} \mathrm{~J}$. Even so, the energy of the 2004 Indian Ocean tsunami is still only $0.3 \%$ of the total radiated earthquake energy suggested by Lay et al. (2005). In Table 2, we also compare the 2004 Indian Ocean tsunami with other historical and ancient tsunamis. The table shows that although the energy of the 2004 Indian Ocean tsunami is approximately 40 times higher than Papua New Guinea tsunami, there are certainly historical tsunamis with considerably higher energies. Moreover, Table 2 indicates that tsunamis caused by other sources, e.g. the 8100 BP Storegga slide and the 142 My BP Mjølnir as- teroid, have caused much higher tsunami energies. It is also noted that even though there are orders of magnitude less casualties resulting from the both the 1883 Krakatau explosion tsunami and the M 9.51964 Chile earthquake tsunami, their energies may have been higher than the energy of the 2004 Indian Ocean tsunami. Furthermore, the 1964 Alaska tsunami had approximately the same energy as the 2004 Indian Ocean tsunami, but in comparison it caused very few casualties. This illustrates that factors other than the tsunami energy are important for the extent of destruction, e.g. the displaced water volume, the population patterns close to the generation area, and the vulnerability. 

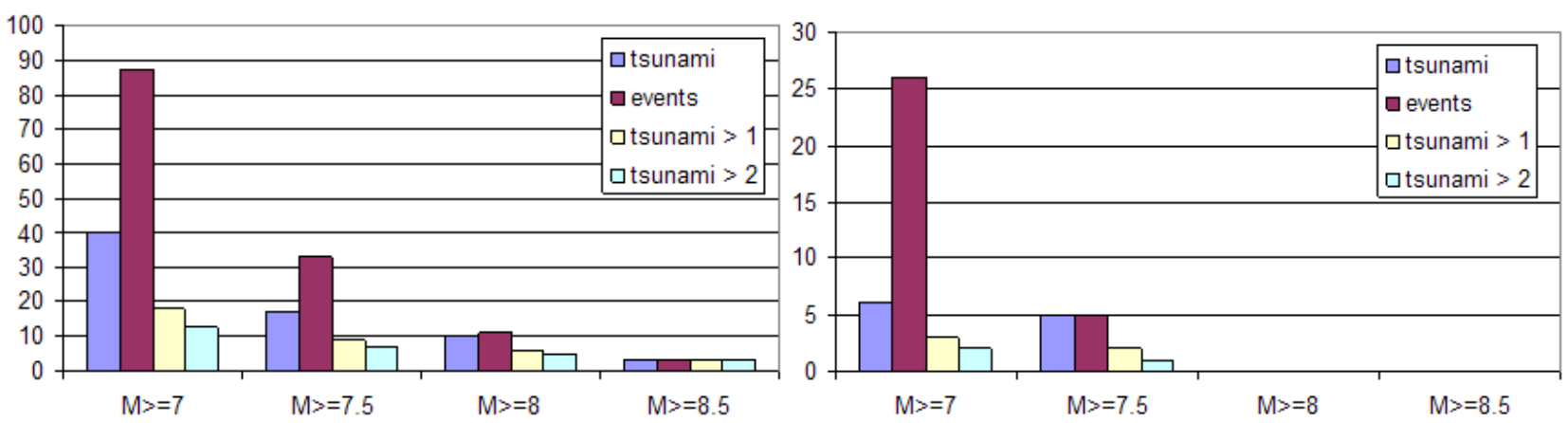

Fig. 9. Tsunami statistics from the South American and Sunda arc subduction zones, for magnitudes above 7.0, 7.5, 8.0 and 8.5, respectively. The red column is the total number of shallow events reported, the blue is the total number of tsunamis reported, and the yellow and green are the number of tsunamis reported above 1 and $2 \mathrm{~m}$, respectively. The data are obtained from the Pacific Tsunami Warning Center data base (http://www.prh.noaa.gov/ptwc/) and Engdahl et al. (1998).

Table 3. Scenario earthquakes used in this study with calculated maximum characteristic surface elevations along western Thailand.

\begin{tabular}{lll}
\hline Scenario & Location of epicenter & $\begin{array}{l}\text { Calculated surface eleva- } \\
\text { tion [m] }\end{array}$ \\
\hline M 9.3 & $\begin{array}{l}\text { 26 December 2004 earthquake, Simeulue island } \\
\text { M 8.5 south }\end{array}$ & $\begin{array}{l}\text { Between Sumatra and Nicobar } \\
\text { NicbarNicobar }\end{array}$ \\
& Between Nicobar and Andaman & $1-2$ \\
M 8.5 north & Between Sumatra and Nicobar & $1-2$ \\
M 7.5 south & Between Nicobar and Andaman & $\sim 0.5$ \\
M 7.5 mid & North of Andaman & $\sim 0.5$ \\
M 7.5 north & & $\begin{array}{l}\text { Less than } 0.2 \\
\text { (behind Andaman) }\end{array}$ \\
M 7.0 & Between Sumatra and Nicobar & $\sim 0.2$ \\
\hline
\end{tabular}

\section{Potential future seismic scenarios}

\subsection{Assumptions, scaling relations and source parameters}

The assessment of potential future tsunamis is approached through scenarios, treating the probabilism through return periods. A starting point here was found through an analysis of empirical tsunami data from the Pacific Tsunami Warning Center data base, showing that for South America, Japan and the Sunda arc combined $34 \%$ of the shallow events with $M \geq 7$ are reported to have generated a tsunami, $71 \%$ for $M \geq 7.5$ and $84 \%$ for $M \geq 8.0$. Most of these tsunamis are small, since less than $20 \%$ of them have reported maximum water levels or run-up heights of $3 \mathrm{~m}$ or more. The numbers for South America and the Sunda arc are shown separately in Fig. 9 indicating that significant tsunamis from earthquakes below M 8 are very rare. The selection of the scenario magnitudes are in part based on this empirical assessment, in part on tsunami modelling efforts that show the same, and in part on the fact that events above M 8.5 are not likely to occur for a very long time (see the assessment below of return periods).

The process of defining scenarios also included an assessment of both contemporary (Engdahl et al., 1998; Engdahl and Villaseñor, 2002) and historical seismicity (e.g., Bilham et al., 2005), as well as the presumed stress situation in the region where earthquakes potentially generating tsunamis affecting western Thailand can occur. The M 8.5, M 7.5, and M 7.0 scenarios listed in Table 3 and shown in Fig. 10, reflect a gradually decreasing potential for large ruptures northwards along the Sumatra-Nicobar-Andaman segment; the subduction rates are northward decreasing from about 50 to about $10 \mathrm{~mm} /$ year (Petersen et al., 2004; Lay et al., 2005; Bilham et al., 2005). The scenarios are located to be worst case with respect to tsunamis affecting the coastal regions of Thailand, in the sense that they are placed between the main 

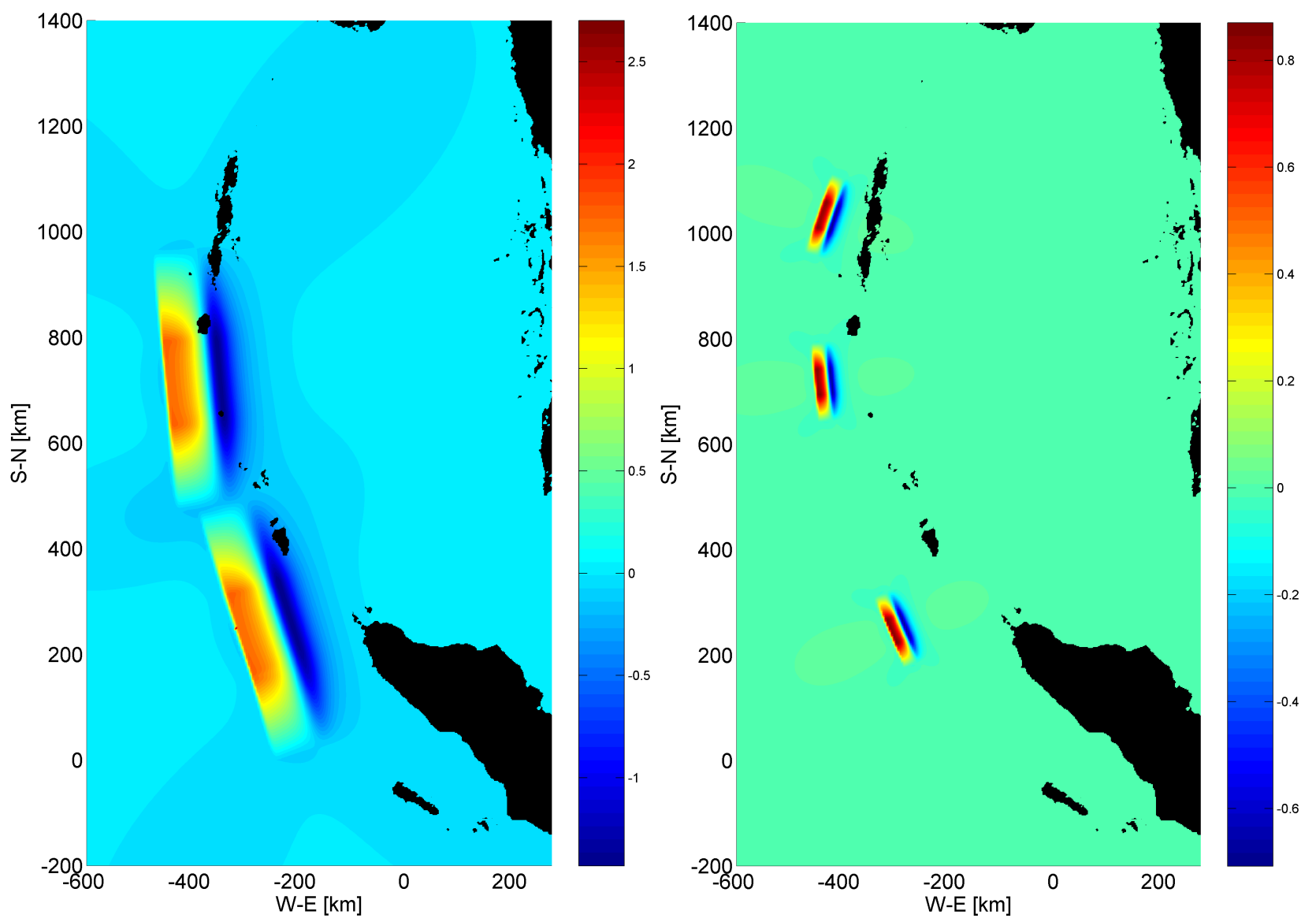

Fig. 10. Initial surface elevation for the M 8.5 south and north scenarios (left panel), and the M 7.5 south, mid, and north scenarios (right panel), cfr. Table 1 and Table 3. The central location of the M 7.0 scenario is identical to the M 7.5 south scenario, and the central location of the M 7.5 mid scenario is identical to the M 8.5 north scenario. The colour bars indicate the surface elevations in $\mathrm{m}$.

island chains with open access eastwards (note that this is neither specifically supported nor excluded tectonically).

Another assumption behind the scenarios is that there is a tectonic barrier near the Simeulue island which is expected to cause north-westward ruptures on the northern side and south-eastward ruptures on the southern side (Singh et al., 2005; DeShon et al., 2005), making it unlikely that a megathrust earthquake can start south of this barrier region and rupture in a north-westerly direction far enough to generate tsunamis affecting Thailand. Further southeast along the subduction zone, however, the 26 December 2004 event may even have increased the risk for large earthquakes (Stone and Kerr, 2004; Schiermeier, 2005), in a similar way as for the Great Sumatra Fault (McCloskey et al., 2005; Nalbant et al., 2005).

The source parameters for the scenarios are shown in Table 1 together with the M 9.28 event. While the scenarios are very simple and uniform, they are at the same time based on scaling properties guided by a combination of theoretical (Aki and Richards, 1980) and empirical relations (Wells and
Coppersmith, 1994). For subduction zone events the width can grow more than it can do in plate margin areas, where the sensitivity to magnitude becomes more critical since larger earthquakes (say, above M 6.7) that reach the depth of the seismogenic (brittle) zone can grow only in the horizontal direction (e.g., Scholz, 2002). This means, for example, that the fault length of the scenario earthquakes (Table 1) decreases with decreasing magnitude somewhat more rapidly than the slip, which in part is related to decreasing rigidities and in part to non-linearities in scaling relations for large earthquakes. In a scaling sense this means that the tsunamigenic potentials decrease less rapidly than the seismic moment of the causative earthquake.

The scaling properties used for the scenario events were also guided by available analyses for the 28 March 2005 Nias M 8.6 earthquake (Ammon et al., 2005; Walker et al., 2005), where the slip was highest in the central parts of the fault zone, consistent with the tapering of the sources in Table 1. The epicentre of the Nias earthquake was $2-300 \mathrm{~km}$ south from the epicentre of the 26 December 2004 earthquake and 
the main part of the rupture extended south-eastwards from there.

The fault lengths for the $\mathrm{M} 8.5,7.5$ and 7.0 scenario events in Table 1 are seen to be 480,150 , and $84 \mathrm{~km}$, the widths are 100,30 and $17.5 \mathrm{~km}$, and the slips are peaking at 7.3, 3.6, and $2.6 \mathrm{~m}$. The average rigidities are set in Table 1 to $30 \mathrm{GPa}$ (M 8.5), $20 \mathrm{GPa}$ (M 7.5), and $15 \mathrm{GPa}$ (M 7.0), reflecting the decreasing depths of the ruptures with decreasing magnitudes. The rupture models have been tapered down to zero slip at both ends, maintaining the moment release and the corresponding magnitude. The decreasing rigidity for more shallow ruptures is important since this results in relatively larger dislocations for the smaller events, provided they are so shallow that they rupture through less consolidated sediments. These dislocations are averages, however, while in reality they should be expected to follow a distribution which allows for both smaller and larger slips for any given magnitude, with a similar variation in seabed dislocations.

\subsection{Return periods}

The M 8.5 event is in subsequent sections shown to represent a crucial magnitude in terms of tsunami effects for Thailand, therefore a key issue in the subsequent risk assessment will be to estimate the return period for such magnitude earthquakes, even though such estimates are not normally done for scenarios. This problem has been approached along two paths, through magnitude-frequency regressions on available seismicity catalogues, and through tectonic considerations, related to average slip rates for the different parts of the subduction zone. The former approach is very uncertain in this case because of the short observational period, and it gives much longer return periods than the tectonic approach, which is based on the assumption that the fault is locked and that the seismic coupling is complete, which we know is true only to some extent. There are, moreover, greatly varying conditions along the trench, including asperities, adding uncertainty also to the tectonic approach.

Using seismological data from 1964 through 2002 (Engdahl et al., 1998; Engdahl and Villaseñor, 2002; http: //earthquake.usgs.gov/research/data/centennial.php), we find for the Sumatra Trench a magnitude-frequency relation which yields a return period of 195 years for M 8.5 and 1140 years for M 9.3. Due to the decreasing convergence rates northwards this is, however, less relevant as a reference for the Nicobar-Andaman subduction zone, where we find a seismicity based return period of 1100 years for M 8.5, and even lower when the zone is further segmented northwards. It is obvious that 36 years of seismicity data is totally insufficient for estimating return times that are much longer than this, especially since temporal variations in seismicity can be significant also in subduction zones.

Return times as inferred from subduction rates provide in contrast lower bound estimates, assuming complete coupling. An average subduction rate of $30 \mathrm{~mm} /$ year (average of 48 in the southern segment and $14 \mathrm{~mm} /$ year at the northern segment, Bilham et al., 2005; Vigny et al. 2005) for the trench perpendicular convergence on the southern segment, combined with an assumption that a M 8.5 event will release $6 \mathrm{~m}$ of slip, gives a return period of 200 years for the southern segment, while a rate of $14 \mathrm{~mm} /$ year for the northern segment gives 430 years. For a megathrust event of M 9+ along the entire northern Sumatra subduction zone an average slip of $13 \mathrm{~m}$ and a rate of $48 \mathrm{~mm} /$ year will give a tectonicallyderived lower bound return period of 270 years, while the seismicity indicated as much as 1140 years. The seismic coupling factor can explain some of this difference, since a coupling value below 1.0 will give a longer tectonically inferred return period. It is therefore not unreasonable to assume also that an overestimated seismic coupling will increase the megathrust return time to well above 270 years, providing a basis for adjusting the value to about 400 years for a M 9+ event along the northern part of the Sumatra trench. Another reason for this upward adjustment of the subduction-based recurrence interval is the fact that the Sumatra trench considered here includes parts of the zone (south of Simeulue) that is considered to have potentials for rupturing only southwards.

A similar reasoning for an M 8.5 event on the southern Nicobar-Andaman segment, where the return periods were 200 and 2700 years as derived from subduction and seismicity, respectively, will lead to an adjusted value of 400 years. For the northern segment, where subduction rates give 430 years and the seismicity 1800 years, we have adjusted to a value of 800 years. Admittedly, these adjustments include a clear element of expert judgement in a situation with considerable uncertainties. When applying this adjustment, a lot more confidence has been given to the tectonically-derived estimates than to the earthquake catalogue which admittedly covers only 36 years of reasonably unbiased data.

At the megathrust level, the only viable scenario for an event affecting the coastal areas of Thailand is one which starts in the northern part of the Sumatra trench and ruptures northwards similar to the 2004 earthquake, not the least because of the tectonic barrier near the Nias 2005 earthquake. Singh et al. (2005) maintain that this barrier is in the form of a lithospheric-scale boundary which starts near the Simeulue Island and continues up to the east of the Nicobar Islands, eventually joining the Sumatra Fault in the north.

In a risk context it should be noted that it is the combined occurrence rates of a megathrust earthquake with the rates of more "local" M 8.5 earthquakes that define the M 8.5+ return periods related to tsunami potentials for Thailand. For the southern segment both of these return periods were 400 years, leading to a combined return period of 200 years (two events over 400 years). For the northern segment the two return periods were 400 and 800 years, so the combined return time in this case will be 270 years (three events over 800 years). These numbers reflect the occurrence rates of the earthquakes, and it is important to keep in mind here that all 

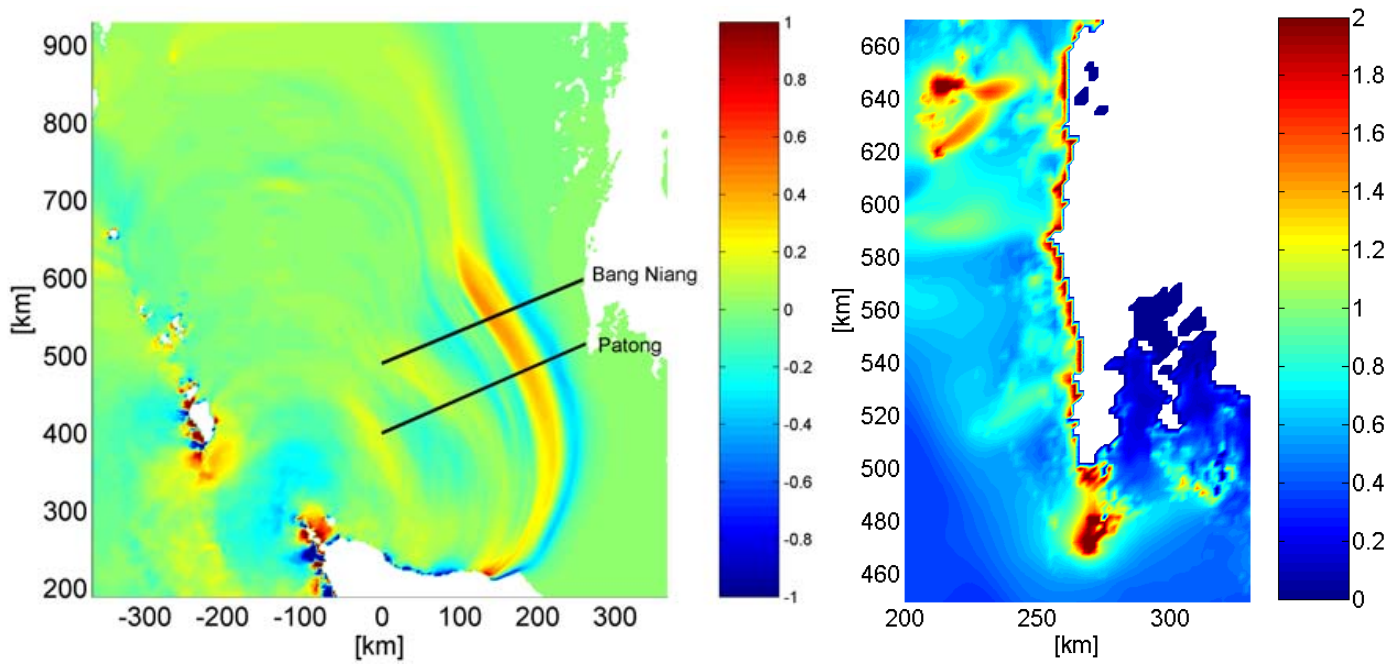

Fig. 11. Left panel: Snapshot of the M 8.5 south scenario tsunami surface elevation 80 min after the earthquake. The cross sections indicate the location of the depth profiles used for the one-dimensional numerical simulations. Right panel: Maximum surface elevations for the M 8.5 south scenario during the whole computational time of $6 \mathrm{~h}$ for the Thailand coast. Both colour scales are elevations in $\mathrm{m}$.

of those below megathrust level will not necessarily cause tsunamis, in particular since this requires shallow ruptures.

There is a remaining issue which is equally important as the return period, namely when these events are likely to occur within the occurrence cycle. Paleoseismological research in different subduction zones (e.g., Satake et al., 1996; Clague, 1997; Cisternas, 2005) has indicated that the megathrust events are relatively regular in their occurrence. The implication of this is that another M 9+ event in the Sumatra subduction zone with potential tsunami effects on Thailand is not likely to occur before at least 400 years after the 2004 megathrust earthquake. For the M 8 to 8.5 tsunamigenic events, however, the cyclicity is less predictable (i.e., more Poisson distributed), but even for such events the probability of occurrence will be quite low for a long time after 2004 , increasing gradually with time. The reason for this is that the 26 December 2004 rupture covered the entire subduction zone up to north of Andaman, thereby releasing accumulated stress over the whole region where the present scenarios are located.

\section{Modelling of tsunami scenarios}

Using the method described in Sect. 2.2, the slip values given in Table 1 were used to calculate initial sea surface elevations generated by the potential earthquake scenarios as shown for the M 8.5 and M 7.5 scenarios in Fig. 10. The initial sea surface elevations of the scenarios were used as initial conditions for the two-dimensional (depth-averaged with two horizontal dimensions) tsunami simulations, as documented in the following. In addition, one-dimensional (depth-averaged with one horizontal dimension) simulations along the pro- files given in Fig. 1 and Fig. 11 were performed. The twodimensional and the one-dimensional models are described in Sects. 3 and 5.1, respectively. It should be noted that for earthquake scenarios with magnitudes less than 9, the generated waves will be more affected by wave dispersion than the 2004 Indian Ocean tsunami was. Effects of dispersion are only accounted for in the one-dimensional simulations.

The results were analysed along the western coast of Thailand using time series and snapshots. Particular emphasis is given to the locations Patong and Bang Niang, as results with both one-dimensional and two-dimensional models are provided at those locations. Moreover, maximum surface elevations for the whole simulation time were analysed along the coast. The maximum surface elevation maps did not reveal fluctuations along the coast, partly because shorter earthquake segments limit effects of wave interference. Hence, the results obtained at Patong and Bang Niang represent reasonable values for the maximum surface elevation along western Thailand from Phuket and northwards.

The maximum surface elevations obtained for the different scenarios are summarised in Table 3, which shows that for the M 8.5 scenarios maximum surface elevations of 1.5$2 \mathrm{~m}$ are generated along western Thailand. For the scenarios with $\mathrm{M} \leq 7.5$, waves with surface elevation larger than $0.5 \mathrm{~m}$ are not produced along western Thailand. It is noted that the M 7.0 scenario produces larger waves than the northern M 7.5 scenario along the coasts of Thailand since the latter earthquake is mainly shielded by the Andaman Islands with regard to Thailand. Detailed results for all the scenarios analysed are too extensive to be presented here; however, details for the M 8.5 south scenario are given as an example in the following. 

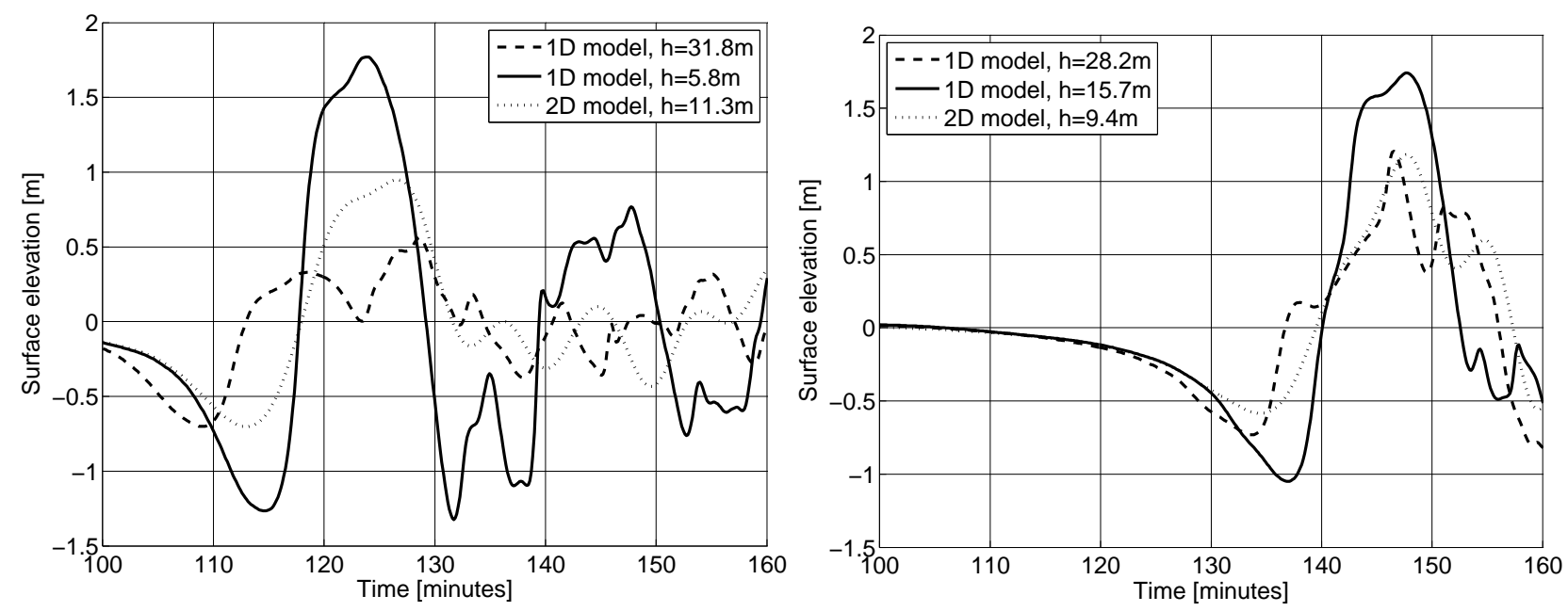

Fig. 12. Time series of the surface elevation at different depths for the M 8.5 south scenario with two- and three-dimensional models; left panel close to Patong, right panel close to Bang Niang.

\subsection{Magnitude 8.5 scenario results}

The M 8.5 south scenario serves as an example of a possible future tsunamigenic earthquake and it also represents a design tsunami for the western coast of Thailand, for reasons elaborated in Sect. 6. A snapshot of the surface elevation after 80 minutes for the southern M 8.5 scenario together with the maximum surface elevation during a time period of $6 \mathrm{~h}$ after the rupture time is given in Fig. 11. The latter shows maximum surface elevations of 1-2 $\mathrm{m}$ along the coast of Thailand from the Phuket Island and northwards.

Effects of non-linearity and dispersion are modelled with a standard one-dimensional (depth averaged with one horizontal dimension) Boussinesq model (Peregrine, 1972), solved on a staggered, non-uniform grid (keeping the Courant number constant) using finite differences, where the shoreline is represented as an impermeable wall. The one-dimensional simulations are performed along the cross-sections towards Patong and Bang Niang shown in Figs. 1 and 11. The depth profiles along the cross-sections are first extracted from the two-dimensional grid by bi-linear interpolation, and then refined to give the finest resolution of $25 \mathrm{~m}$ near the coast. Assuming uni-directional wave propagation landward along the cross-section, the surface elevations from the two-dimensional simulations are used as initial conditions for surface elevation and wave current speeds in the one-dimensional simulations, as described by Glimsdal et al. (2006). It is emphasised that two-dimensional effects including radial spread, reflections from surrounding islands, refraction, focussing, and interference are neglected. The resulting time series along the Patong and Bang Niang cross sections are shown in Fig. 12. Convergence of the results from the one-dimensional numerical model was confirmed by grid refinements, generally showing discrepancies of less than $1 \%$ in the surface elevation. The gentle characteristics of the waves shown in Fig. 12 could indicate that in contrast to the 2004 Indian Ocean tsunami, a magnitude 8.5 or smaller earthquake is not likely to provide breaking waves.

It is noted that the one-dimensional model gives somewhat larger surface elevations than the two-dimensional model for comparable depths. Because the tsunami front is more or less perpendicular to the cross sections (see Fig. 11), the three dimensional effects listed above are not assumed to have a large effect for the first wave pulse arriving. Moreover, the onedimensional model includes higher order effects and a grid resolution of about one hundredth of the two-dimensional one, which suggest that the one-dimensional model represents the first pulse better than the two-dimensional model.

For this scenario, which is recommended as design basis on short to medium term, the best estimate of the maximum tsunami surface elevation is found in the range $1.5-2 \mathrm{~m}$ above mean sea level as shown in Figs. 11 and 12. These elevations do not take into account variations in tides. The normal high tide in the area of interest is approximately $+0.80 \mathrm{~m}$ above the mean sea level, and twice a month, during the spring tide, the water level is as much as $+1.5 \mathrm{~m}$ above this level.

\section{Risk assessment and mitigation measures}

The risk associated with potential tsunamis towards Thailand is treated in detail by NGI (2006), and by Nadim and Glade (2006). They reported that the 2004 Indian Ocean tsunami caused very few casualties (none recorded in the available databases) in the coastal areas of Thailand where the maximum water level was less than $3 \mathrm{~m}$, and that almost all the fatalities in Thailand occurred in areas where the maximum water level was more than $5 \mathrm{~m}$ above mean sea level. It is 
noted that in Sri Lanka many casualties occurred at water levels less than $3 \mathrm{~m}$. The latter illustrates the importance of settlement patterns for the risk assessment. The numerical tsunami simulations above show that the maximum surface elevation along the western coast of Thailand for the magnitude 8.5 scenario is $1.5-2 \mathrm{~m}$, and possibly $2.5-3.0 \mathrm{~m}$ if the tsunami occurs at high tide (the probability of the simultaneous occurrence of two independent extreme events, a design tsunami and an extreme high tide or a storm, is so low that it contributes very little to the total risk). Hence, very few casualties in Thailand should be expected from a magnitude 8.5 scenario.

NGI (2006) as well as Nadim and Glade (2006) concluded that the largest credible earthquake that could cause a tsunami towards western Thailand within the next 50 to 100 years is a magnitude 8.5 earthquake, and the potential risk from tsunamis to human life and property in Thailand can be regarded as tolerable within this time frame. They reached this conclusion through an iterative process combining; (i) return periods and uncertainty in cyclicity of major tsunami-triggering events; (ii) the results of the numerical tsunami simulations; (iii) settlements and damage patterns; (iv) probabilistic evaluations; and (v) comparisons with suitable societal risk acceptance criteria. It is, however, noted that the tsunami risk will gradually increase from tolerable to highly unacceptable with time, because the seismic hazard increases.

One cannot influence the earthquake and tsunami hazard, but one can mitigate their consequences. To this end, several mitigation measures are proposed by NGI (2006, executive summary). The most important of these measures are: (i) new requirements to land-use planning and new building codes to reduce exposure to and/or consequences of future tsunamis; (ii) escape routes that lead to areas or places safe from the tsunami; (iii) artificial walls or dikes to limit the impact and inundation level of tsunamis; (iv) raising the ground level (vertical land reclamation) where buildings are to be constructed in the future; (v) ensuring that future buildings will not be damaged and that sleeping areas are at a level that is safe from tsunamis; and (vi) ensuring public awareness for many generations.

\section{Concluding remarks}

The 2004 Sumatra-Andaman earthquake rupture initiated west of the northern tip of Sumatra, near the Simeulue Island. Within ten minutes, the earthquake slip propagated about $1200 \mathrm{~km}$ northwards from the epicentre, generating the most destructive tsunami in recorded history.

Reconstructing the complex earthquake slip distribution using available seismic and geodetic information, and simulating the following 2004 Indian Ocean tsunami, has been attempted by numerous authors. In the present paper, the method for describing the slip of the Sumatra-Andaman earthquake involves several simplifications (e.g. uniform slip in the dip direction), as the method is applicable also to future scenarios. Yet, the earthquake source largely complies with the available seismic and geodetic information in literature. In addition, both the sea level records and the run-up height distribution agree well with the results of the tsunami simulation, which indicates that the slip distribution of the Sumatra-Andaman earthquake is satisfactorily incorporated in the model. Nevertheless, discrepancies due to the synthetic source, grid effects, and local effects are present.

The Sunda arc is an active fault zone with frequent earthquakes that will generate tsunamis again. Our study of earthquake statistics and plate tectonics concludes that it will take at least 300 to 400 years before an event of similar magnitude and destructions as the Sumatra-Andaman earthquake will occur again north of the tectonic barrier near Simelulue, as much of the energy that was accumulated along the northern part of the Sunda arc subduction zone is now released. For earthquake scenarios of magnitude 8.5 , and with the potential for generating tsunamis impacting western Thailand, the lower bound return period is found to be 200 years, however, the cyclicity is less predictable.

The 2004 Indian Ocean tsunami shows the possibly devastating effects of tsunamis generated by megathrust earthquakes. The largest credible earthquake that can cause tsunamis towards western Thailand within the next 50-100 years is a magnitude 8.5 earthquake (NGI, 2006; Nadim and Glade, 2006). Limiting our investigation of tsunami hazard to western Thailand, we show that future earthquakes of magnitudes less than or equal to 8.5 are not likely to generate waves with maximum surface elevations larger than $3 \mathrm{~m}$ on high tide. Because the 2004 Indian Ocean tsunami caused very few casualties in Thailand where the maximum water level was less than $3 \mathrm{~m}$, few casualties should also be expected in Thailand from a magnitude 8.5 scenario.

NGI (2006) as well as Nadim and Glade (2006) concluded that the potential risk from tsunamis to human life and property in Thailand can be regarded as tolerable within the next 50 to 100 years, but that the tsunami risk will gradually increase with time.

Acknowledgements. The paper is based on a project to assist the authorities in Thailand with evaluating the future tsunami risk. This project was financed by the Royal Norwegian Ministry of Foreign Affairs, and conducted in cooperation with the Department of Mineral Resources in Thailand (DMR) and the Coordinating Committee for Geoscience Programs in East and South East Asia (CCOP). This work was supported by the Research Council of Norway (RCN) under grant 154831, and by the International Centre for Geohazards partly financed by RCN, NGI, and NORSAR. We would like to thank K. Karlsrud and F. Nadim for helpful comments on this paper. We also would like to thank project leader K. Karlsrud and co-workers B. V. Vangelsteen, F. Nadim, P. Gauer, K. Atakan, M. B. Sørensen, B. Heyerdahl, A. Tennøy, L. McNeill, T. Henstock, A. Tørum, Ø. Arntsen, and S. Bjørdal for helpful assistance throughout the project preceding this paper. The authors 
are indebted to B. Gjevik and P. Heinrich for assistance regarding the coupling between seismology and tsunami generation. Finally, we thank F. Schindele and two anonymous referees for constructive reviews of this paper. The present article is contribution No. 130 from the International Centre for Geohazards, Oslo, Norway.

Edited by: E. Pelinovsky

Reviewed by: F. Schindele and two other referees

\section{References}

Aki, K. and Richards, P. G.: Quantitative seismology, Freeman, San Francisco, California, 1980.

Ammon, C. J., Ji, C., Thio, H.-K., Robinson, D., Ni, S., Hjortleifsdottir, V., Kanamori, H., Lay, T., Das, S., Helmberger, D., Ichinose, G., Polet, J., and Wald, D.: Rupture process of the 2004 Sumatra-Andaman earthquake, Science, 308, 1127-1133, 2005.

Banerjee, P., Pollitz, F. F., and Bürgmann, R.: The size and duration of the Sumatra-Andaman Earthquake from Far-Field Static Offsets, Science, 308, 1769-1772, 2005.

Bilek, S. L. and Lay, T.: Rigidity variations with depth along interplate megathrust faults in subduction zones, Nature, 400, 443446, 1999.

Bilham, R.: A flying start, then a slow stop, Science, 308, 1126, 2005.

Bilham, R., Engdahl, R., Fedl, N., and Satyabala, S. P.: Partial and complete rupture of the Indo-Andaman plate boundary 18472004, Seis. Res. Lett., 76(3), 299-311, 2005.

Bondevik, S., Løvholt, F., Harbitz, C. B., Mangerud, J., Dawson, A., and Svendsen, J. I.: The Storegga slide tsunami - comparing field observations with numerical simulations, Mar. Petroleum Geology, 22, 195-208, 2005.

Borrero, J. C., Synolakis, C. E., and Fritz, H.: Northern Sumatra Field Survey after the December 2004 Great Sumatra Earthquake and Indian Ocean Tsunami, Earthquake Spectra, 22(3), 93-104, 2006.

Choi, B. H., Pelinovsky, E., Kim, K. O., and Lee, J. S.: Simulation of the trans-oceanic tsunami propagation due to the 1883 Krakatau volcanic eruption, Nat. Hazards Earth Syst. Sci., 3, 321-332, 2003,

http://www.nat-hazards-earth-syst-sci.net/3/321/2003/.

Cisternas, M., Atwater, B. F, Torrejon, F., Sawai, Y., Machuca, G., Lagos, M., Eipert, A., Youlton, C., Salgado, I., Kamataki, T., Shishikura, M., Rajendran, C. P., Malik, J. K., Rizal, Y., and Husni, M.: Predecessors of the giant 1960 Chile earthquake, Nature, 437, 404-407, 2005.

Clague, J. J.: Evidence for large earthquakes at the Cascadia subduction zone, Rev. Geophys., 35, 439-460, 1997.

Chlieh, M., Avouac, J.-P., Hjorleifsdottir, V., Song, T.-R. A., Ji, C., Sieh, K., Sladen, A., Hebert, H., Prawirodirdjo, L., Bock, Y., and Galetzka, J.: Coseismic Slip and Afterslip of the Great Mw 9.15 Sumatra-Andaman Earthquake of 2004, Bull. Seismol. Soc. Am., 97-A, in press, 2006.

Collection of videos of the 26th December Indian Ocean tsunami: http://www.asiantsunamivideos.com, 2005.

DeShon, H. R., Engdahl, E. R., Thurber, C. H., and Brudzinski, M.: Constraining the boundary between the Sunda and Andaman subduction systems: Evidence from the $2002 \mathrm{Mw} 7.3$ Northern Sumatra earthquake and aftershock relocations of the 2004 and 2005 great earthquakes, Geophys. Res. Lett., 32, L24307, doi:10.1029/2005GL024188, 2005.

Engdahl, E. R., van der Hilst, R. D., and Buland, R. P.: Global teleseismic earthquake relocation with improved travel times and procedures for depth determination, Bull. Seism. Soc. Am., 88, 722-743, 1998.

Engdahl, E. R. and Villaseñor, A.: Global Seismicity: 1900-1999, in: International Handbook of Earthquake and Engineering Seismology, edited by: Lee, W. H. K., Kanamori, H., Jennings, P. C., and Kisslinger, C., Part A, Chapter 41, pp. 665-690, Academic Press, 2002.

GEBCO: The General Bathymetric Chart of the Oceans, http:// www.ngdc.noaa.gov/mgg/gebco/gebco.html, 2006.

Geological Survey of India: A report on the Sumatra-Andaman earthquake and tsunami of 26 December 2004, Institute report, 2005.

Gill, A. E.: Atmosphere-Ocean Dynamics, International Geophysics Series, 30, Academic Press Inc., ISBN: 0-12-451450-2, 1982.

Glimsdal, S., Pedersen, G. K., Atakan. K., Harbitz, C. B., Langtangen, H. P., and Løvholt, F.: Propagation of the Dec. 262004 Indian Ocean Tsunami: effects of dispersion and source characteristics, Int. J. Fluid Mech. Res., 33(1), 14- 33, 2006.

Glimsdal, S., Pedersen, G. K., Dypvik, H., Langtangen, H. P., and Shuvalov, V.: Tsunami generation and propagation from the Mjølnir asteroid impact, Meteorit. Planet. Sci., in press, 2006.

Harbitz, C. and Pedersen, G.: Model Theory and Large Water Waves, Due to Landslides, Preprint Series, vol. 4, Department of Mathematics, University of Oslo, 1992.

Intergovernmental Oceanographic Commission of UNESCO: Tsunami glossary, available at: http://ioc3.unesco.org/itic/, 2006.

Ishii, M., Shearer, P. M., Houston, H., and Vidale, J. E.: Extent, duration and speed of the 2004 Sumatra-Andaman earthquake imaged by the Hi-Net array, Nature, 435, 933-936, 2005.

Iwan, W. D.: Preface to the Special Issue on the Great Sumatra Earthquakes and Indian Ocean Tsunamis of 26 December 2004 and 28 March 2005, Earthquake Spectra, 22(3), xi-xii, 2006.

Jaffe, B. E., Borrero, J. C., Prasetya, G. S., Peters, R., McAdoo, B., Gelfenbaum, G., Morton, R., Ruggiero, P., Higman, B., Dengler, L., Hidayat, R., Kingsley, E., Kongko, W., Lukijanto, Moore, A., Titov, V., and Yuliantom, E.: Northwest Sumatra and Offshore Islands Field Survey after the December 2004 Indian Ocean Tsunami, Earthquake Spectra, 22(3), 105-135, 2006.

Japanese survey team: The 2004 Indian Ocean Tsunami Disaster Survey Report, Web page http://www.tsunami.civil.tohoku.ac.jp/ sumatra2004/report.html, 2006a.

Japanese survey team: Compilation of web links, http://www.drs. dpri.kyoto-u.ac.jp/sumatra/index-e.html, 2006b.

Kajiura, K.: Tsunami energy in relation to parameters of the earthquake fault model, Bull. Earthquake Res. Institute, 56, 415-440, 1981.

Kanamori, H.: Seismological Aspects of the December 2004 Great Sumatra-Andaman Earthquake, Earthquake Spectra, 22(3), 112, 2006.

Karlsrud, K., Bungum, H., Harbitz, C. B., Løvholt, F., Vangelsten, B. V., and Glimsdal, S.: Strategy for re-construction in Thailand following the 26 December 2004 tsunami event, in: International Conference on Geotechnical Engineering for Disaster Mitigation \& Rehabilitation, edited by: Chu, J., Phoon, K. K., and Yong, K. 
Y., World Scientific Publishing Company, ISBN 981-256-469-1, 2005.

KNMI web page: Tsunami Observations by the Echo-Sounder on Yacht Mercator, Phuket, http://www.knmi.nl/VinkCMS/ newsdetail.jsp?id=19222, 2005.

Krüger, F. and Ohrnberger, M.: Tracking the rupture of the $\mathrm{Mw}=9.3$ Sumatra earthquake over $1,150 \mathrm{~km}$ at teleseismic distance, Nature, 435(7044), 937-939, 2005.

Lay, T., Kanamori, H., Ammon, C., Nettles, M., Ward, S. N., Aster, R. C., Beck, S. L., Bilek, S. L., Brudzinski, M. R. , Butler, R., DeShon, H. R., Ekström, G., Satake, K., Sipkin, S.: The great Sumatra-Andaman earthquake of December 26, 2004, Science, 308, 1127-1133, 2005.

Liu, P.-L. F., Lynett, P., Fernando, H., Jaffe, B. E., Fritz, H., Higman, B., Morton, R., Goff, J., and Synolakis, C.: Observations by the International Tsunami Survey Team in Sri Lanka, Science, 308(5728), 1595-1595, 2005.

Løvholt, F., Harbitz, C. B., and Haugen, K. B.: A parametric study of tsunamis generated by submarine slides in the Ormen Lange/Storegga area off western Norway, Mar. Petroleum Geology, 22, 219-231, 2005.

McCloskey, J., Nalbant, S. S., and Steacy, S.: Earthquake risk from co-seismic stress, Nature, 434, 291, 2005.

Merrifield, M. A., Firing, Y. L., Aarup, T., Agricole, W., Brundrit, G., Chang-Seng, D., Farre, R., Kilonsky, B., Knight, W., Kong, L., Magori, C., Manurung, P., McCreery, C., Mitchell, W., Pillay, S., Schindele, F., Shillington, F., Testut, L., Wijeratne, E. M. S., Caldwell, P., Jardin, J., Nakahara, S., Porter, F.-Y., and Turetsky, N.: Tide gauge observations of the Indian Ocean tsunami December 26, 2004, Geophys. Res. Lett., 32, L09603, doi:10.1029/2005GL022610, 2005.

Mei, C. C.: The applied dynamics of ocean surface waves, Adv. Series on Ocean Engineering, 1, World Scientific, London, 1989.

Mesinger, F. and Arakawa, A.: Numerical methods used in atmospheric models, GARP, Publ. Ser. WMO 17, 64 pp, 1976.

Nadim, F. and Glade, T.: On tsunami risk assessment for the west coast of Thailand, edited by: Nadim, F., Pöttler, R., Einstein, H., Klapperich, H., and Kramer, S., ECI Symposium Series, 7, http://services.bepress.com/eci/geohazards/28, 2006.

Nalbant, S. S., Steacy, S., Sieh, K., Natawidjaja, D., and McCloskey, J.: Earthquake risk on the Sunda trench, Nature, 425, 756-757, 2005.

Ni, S., Kanamori, H., and Helmberger, D.: Energy radiation from the Sumatra earthquake, Nature, 434, 592, 2005.

NGI (Norwegian Geotechnical Institute): Tsunami Risk Reduction Measures with Focus on Land Use and Rehabilitation, available at: http://www.ngi.no/files/060215-thail-tsunami_ summary_report-complete.pdf, NGI report no. 20051267-1, 2006.

Okada, Y.: Internal Deformations due to shear and tensile faults in half-space, Bull. Seismic Soc. of Am., 82(2), 1018-1040, 2005.

Okal, E. A. and Synolakis, C. E.: Field Survey and Numerical Simulations: A Theoretical Comparison of Tsunamis from Dislocations and Landslides, Pure Appl. Geophys., 160, 2177-2188, 2003.

Pacific Tsunami Warning Center data base: http://www.prh.noaa. gov/ptwc/, 2005.

Papadopoulos, G. A., Caputo, R., McAdoo, B., Pavlides, S., Karastathis, V., Fokaefs, A., Orfanogiannaki, K., and Valkaniotis, S.:
The large tsunami of 26 December 2004: Field observations and eyewitnesses accounts from Sri Lanka, Maldives Is. and Thailand, Earth Planets Space, 58(2), 233-241, 2006.

Park, J., Song, T.-R. A., Tromp, J., Okal, E., Stein, S., Roult, G., Clevede, E., Laske, G., Kanamori, H., Davis, P., Berger, J., Braitenberg, C., van Kamp, M., Lei, X., Sun, H., Xu, H., and Rosat, S.: Earth's Free Oscillations Excited by the December 2004 Sumatra-Andaman Earthquake, Science, 308, 1127-1133, 2005.

Pedersen, G.: Grid effects on tsunamis in nearshore regions, University of Oslo, Preprint Series nr. 1, ISSN: 0809-439, 1995.

Pedersen, G.: A note on tsunami generation by earthquakes. Preprint Series in Applied Mathematics 4, Dept. of Mathematics, University of Oslo, Norway, 2001.

Petersen, M. D., Dewey, J., Hartzell, S., Mueller, C., Harmsen, S., Frankel, A. D., and Rukstales, K.: Probabilistic seismic hazard analysis for Sumatra, Indonesia and across the Southern Malaysian Peninsula, Tectonophysics, 390, 141-158, 2004.

Peregrine, D. H.: Equations for water waves and the apprtoximations behind them, in: Waves on Beaches, edited by: Meyer, R E., Academic Press, New York, 357-412, 1972.

Satake, K., Shimazaki, K., Tsuji, Y., and Ueda, K.: Time and size of a giant earthquake in Cascadia inferred from Japanese tsunami records of January 1700, Nature, 379, 246-249, 1996.

Schiermeier, Q.: The chaos to come, Nature, 438, 903-906, 2005.

Scholz, C. H.: The mechanics of Earthquakes and Faulting, 2nd Edition, Cambridge University Press, pp 471, 2002.

Singh, S. C., Sibuet, J. C., Malod, J., Rangin, C., Chauhan, A., Carton, H., Apprioul, R., Aryanto, N. C., Begot, J., Cattaneo, A., Creach, R., Crozon, J., Domzig, A., Falleau, N., Graindorge, D., Harmegnies, F., Haryadi, Y., Klingelhoefer, F., Krishna, S. K., Landuré, J.-Y., Le Lann, C., Normand, A., Oggian, G., Restuning Galih, D., Schneider, J.-L., Sultan, N., Taufik, M., Umber, M., and Yamaguchi, H. (Sumatra Aftershocks Team): Sumatra earthquake research indicates why rupture propagated northward, Eos, $86,48,497,502,2005$

Smith, W. H. S., Scharroo, R., Titov, V. V., Arcas, D., and Arbic, B. K.: Satellite Altimeters Measure Tsunami, Oceanography, 18(2), 11-13, 2005.

Stein, S. and Okal E.: Speed and size of the Sumatra earthquake, Nature, 434, 581-582, 2005.

Stone, R. and Kerr, S. A.: Girding for the next killer wave, Science, 310, 1605-1605, 2005.

Subarya, C., Chlieh, M., Prawirodirdjo, L., Avouac, J.-P., Bock, Y., Sieh, K., Meltzner, A. J., Natawidjaja, D. H., and McCaffrey, R.: Plate-boundary deformation associated with the great SumatraAndaman earthquake, Nature, 440, 46-51, 2006.

Synolakis, C. E. and Kong, L.: Runup Measurements of the December 2004 Indian Ocean Tsunami, Earthquake Spectra, 22(3), 67-91, 2006.

Titov, V., Rabinovich, A. B., Mofjeld, H. O., Thomsom, R. E., and Gonzalez, F. I.: The global reach of the 26 December 2004 Sumatra tsunami, Science, 309, 2045-2048, 2005.

Tsujii, Y. and Satake, K.: Tsunami source of the 2004 SumatraAndaman earthquake inferred from tide gauge and satellite data, Bull. Seismol. Soc. Am., 97-A in press, 2006.

University of Poznan: Post-tsunami Field Survey Report, Bangkok, 20 February 2005.

Vigny, C., Simons, W. J. F., Abu, S., Bamphenyu, R., Satirapod, 
C., Choosakul, N., Subarya, C., Socquet, A., Omar, K., Abidin, H. Z., and Ambrosius, B. A. C.: Insight into the 2004 SumatraAndaman earthquake from GPS measurements in southeast Asia, Nature, 436, 201-206, 2005.

Walker, K. T., Ishii, M., and Shearer, P. M.: Rupture details of the 28 March 2005 Sumatra Mw 8.6 earthquake imaged with teleseismic P waves, Geophys. Res. Lett., 32, L24303, doi:10.1029/2005GL024395, 2005.

Wells, D. L. and Coppersmith, K. J.: New empirical relationships among magnitude, rupture length, rupture width, rupture area, and surface displacement, Bull. Seism. Soc. Am., 84, 974-1002, 1994.
Wang, X. and Liu, P. L.-F.: An analysis of 2004 Sumatra earthquake fault plate mechanisms and Indian Ocean tsunami, J. Hydrol. Res., 44(2), 147-154, 2006.

Yalciner, A. C., Perincek, D., Ersoy, S., Presateya, S. G., Hidayat, R., and McAdoo, B.: December 26, 2004 Indian Ocean tsunami, Field Survey (Jan. 21-31, 2005) at north of Sumatra Island, Report for UNESCO IOC, 2005.

Yeh, H., Chadha, R. K., Francis, M., Katada, T., Latha, G., Peterson, C., Raghuraman, G., and Singh, J. P.: Tsunami runup survey along the southeast Indian coast, Earthquake Spectra, 22(3), 173-186, 2006. 